\title{
Probability, Presumptions and Evidentiary Burdens in Antitrust Analysis: Revitalizing the Rule of Reason for Exclusionary Conduct
}

Andrew I. Gavil

Howard University School of Law, agavil@law.howard.edu

Steven C. Salop

Georgetown University Law Center, salop@law.georgetown.edu

This paper can be downloaded free of charge from:

https://scholarship.law.georgetown.edu/facpub/2218

https://ssrn.com/abstract=3523361

University of Pennsylvania Law Review, Forthcoming.

This open-access article is brought to you by the Georgetown Law Library. Posted with permission of the author. Follow this and additional works at: https://scholarship.law.georgetown.edu/facpub

Part of the Antitrust and Trade Regulation Commons, and the Evidence Commons 
Draft 06-11-20

Copyright Andrew I. Gavil \& Steven C. Salop

Not for Quotation Without the Consent of the Authors

Forthcoming in the University of Pennsylvania Law Review

Probability, Presumptions and Evidentiary Burdens in Antitrust Analysis:

Revitalizing the Rule of Reason for Exclusionary Conduct

By

Andrew I. Gavil ${ }^{*} \&$ Steven C. Salop ${ }^{* *}$

\section{Introduction}

From its origins in the Sherman Act of $1890^{1}$ and the Clayton Act of $1914,{ }^{2}$ U.S. antitrust law has prohibited "exclusionary" conduct: conduct by one or more rivals that has a tendency to impede competition by disadvantaging one or more competitors. Such conduct can be challenged under Section 1 of the Sherman Act when it involves concerted action that unreasonably restrains trade. ${ }^{3}$ Exclusionary conduct also can be challenged under Section 2 of the Sherman Act when it

* Professor of Law, Howard University School of Law. The author gratefully acknowledges that the preparation of this article was supported by a 2019 summer research stipend provided by the Howard University School of Law.

** Professor of Economics and Law, Georgetown University Law Center. No outside parties contributed to the funding of this project. The authors would like to thank Professors Jonathan B. Baker, Erik Hovenkamp, Herbert Hovenkamp, Alan J. Meese, A. Douglas Melamed, Fiona Scott Morton, and John M. Newman, and the editors of the University of Pennsylvania Law Review, for helpful comments and discussions of previous drafts of this article.

1 15 U.S.C. $\$ \S 1-7$ (2018).

215 U.S.C. $\$ \S 12-27$ (2018).

${ }^{3}$ Examples include concerted refusals to deal and exclusive dealing. See, e.g., Nw. Wholesale Stationers, Inc. v. Pac. Stationery \& Printing Co., 472 U.S. 284, 290 (1985) ("This Court has long held that certain concerted refusals to deal or group boycotts are so likely to restrict competition without any offsetting efficiency gains that they should be condemned as per se violations of $\S 1$ of the Sherman Act."); ZF Meritor, LLC v. Eaton Corp., 696 F.3d 254, 268 (3d Cir. 2012) ("Under the rule of reason, an exclusive dealing arrangement will be unlawful only if its 'probable effect' is to substantially lessen competition in the relevant market."). 
constitutes an attempt to monopolize ${ }^{4}$ or "monopolization." As one commentator has described it, exclusion has always been a "core concern" of antitrust law. ${ }^{6}$

Beginning with the Supreme Court's 1911 decision in Standard Oil, ${ }^{7}$ both Section 1 and Section 2 have been implemented with a "rule of reason." 8 The rule of reason has served the essential purpose of differentiating conduct that might adversely affect a competitor in the normal course of competition from conduct that handicaps it in a way that significantly impairs the competitive process. The analysis also generally includes direct or circumstantial evidence of "market power," what Justice Stephen Breyer has described as the ability to "make a difference" in the marketplace. ${ }^{9}$

Importantly, and to operationalize it as a useful framework for courts evaluating competitive effects, the rule of reason has evolved into a recognized burden-shifting framework

\footnotetext{
${ }^{4}$ See, e.g., Spectrum Sports, Inc. v. McQuillan, 506 U.S. 447, 455 (1993) (finding that a plaintiff alleging attempt to monopolize "must prove a dangerous probability of actual monopolization, which has generally required a definition of the relevant market and examination of market power").

${ }^{5}$ See, e.g., United States v. Microsoft Corp., 253 F.3d 34, 58 (D.C. Cir. 2001) ("A firm violates $\S$ 2 only when it acquires or maintains, or attempts to acquire or maintain, a monopoly by engaging in exclusionary conduct ....”). Section 3 of the Clayton Act, 15 U.S.C. $§ 14$ (2018), also prohibits a variety of exclusionary practices. See, e.g., Tampa Elec. Co. v. Nashville Coal Co., 365 U.S. 320, 325-29 (1961) (discussing scope and standards for applying Section 3).

${ }^{6}$ Jonathan B. Baker, Exclusion as a Core Competition Concern, 78 Antitrust L.J. 527, 532 (2013) ("[A]nticompetitive exclusion, like anticompetitive collusion, must be understood as a core concern of competition policy.").

${ }^{7}$ Standard Oil Co. of N.J. v. United States, 221 U.S. 1 (1911).

${ }^{8}$ Id. at 61-62; see also Microsoft, 253 F.3d. at 59 (noting that post-Standard Oil, the courts have applied a "rule of reason" approach to cases arising under Sections 1 and 2 of the Sherman Act).

${ }^{9}$ Cal. Dental Ass'n v. FTC, 526 U.S. 756, 782 (1999) (Breyer, J., concurring in part and dissenting in part).
} 
that is common to both Section 1 and Section $2 .{ }^{10}$ The plaintiff, public or private, must meet an initial burden of production sufficient to show that the conduct is likely to be anticompetitive. If it makes that showing, the burden of production shifts to the defendant, who can undermine the plaintiff's evidence and thus prevent the burden from shifting, and/or offer affirmative evidence showing a recognized procompetitive justification likely to eliminate any anticompetitive tendency of its conduct. If it does so, the plaintiff, who bears the ultimate burden of persuasion, can respond in kind by undermining the defendant's evidence of justification, and/or proffering additional evidence to show that the conduct remains likely to have an unreasonably anticompetitive effect. In the context of Section 1, this approach has been described as a "continuum" that can vary in application with the strength of the parties' respective evidence of probable competitive harm. ${ }^{11}$

Despite its origins as a prominent feature of antitrust law, and this shared framework for evaluating anticompetitive conduct of various forms, exclusionary conduct has been the focus of far more robust debate over the last half-century than have many forms of concerted action. Conservative commentary has long been skeptical of exclusionary conduct allegations, even those involving firms with substantial market power. This conservative critique of antitrust law has been highly influential and has facilitated a transformation of antitrust standards of conduct since the 1970s. The combination of objections from the business community, conservative

\footnotetext{
${ }^{10}$ Jonathan B. Baker \& Andrew I. Gavil, Judge Douglas H. Ginsburg and Antitrust Law's Rule(s) of Reason, in 2 Douglas Ginsburg: An Antitrust Professor on the Bench, Liber Amicorum (Nicolas Charbit, ed., forthcoming 2020), https://ssrn.com/abstract=3349853 [https://perma.cc/MZ3C-GA68].

${ }^{11}$ Andrew I. Gavil, Moving Beyond Caricature and Characterization: The Modern Rule of

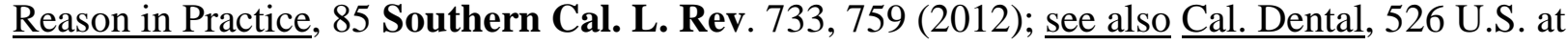
780-81.
} 
academic criticism, and political change launched a generation-long movement toward increasingly more permissive standards of conduct.

Although these changes have taken many forms, all were influenced by a common and repeated message: competition law was over-deterrent. It was prone to condemn conduct that was likely beneficial in many instances, or competitively inconsequential at worst. ${ }^{12}$ Conservatives attributed this tendency to bright line rules of liability, undemanding burdens of proof of anticompetitive effect, lack of appreciation for efficiency, and the limited competence of antitrust decision-makers to correctly differentiate procompetitive from anticompetitive conduct. These commentators also espoused a range of assumptions based on their views that previously suspect types of exclusionary conduct were more likely procompetitive and that highly concentrated markets were likely to perform well. ${ }^{13}$

Critics relied heavily on the assumption that the costs of false positive errors (i.e., erroneous convictions and over-deterrence) far exceeded the costs of false negatives (i.e., erroneous acquittals and under-deterrence). These critics further assumed that the effects of false positives would be lasting because of the enduring impact of court decisions. By contrast, they

${ }^{12}$ See generally Richard A. Posner, Exclusionary Practices and the Antitrust Laws, 41 U. Chi. L. Rev. 506, 515-34 (1974) [hereinafter Posner, Exclusionary Practices] (discussing predatory pricing, vertical mergers, exclusive dealing, and boycotts); Richard A. Posner, The Chicago School of Antitrust Analysis, 127 U. Pa. L. Rev. 925 (1979).

${ }^{13}$ In this article, we differentiate "assumptions" from "presumptions"--a term of more specific meaning in the context of litigation and burdens of proof. As we explain in Parts II and III, infra, many mistaken conservative assumptions have provided the basis for procompetitive presumptions in antitrust law. 
assumed that the effects of false negatives would largely be dissipated by the self-correcting tendencies of markets. ${ }^{14}$

The proscribed cure was a combination of greater economic sophistication, reliance on bright-line rules of non-liability, and lessened reliance on bright-line rules of liability. The influence of this approach did not end with the analysis of particular practices. The goal of preventing false positives provided a focus for the comparative evaluation of alternative legal rules, ${ }^{15}$ and became a barometer for evaluating the scope of antitrust prohibitions. ${ }^{16}$ This translated into a call for a higher evidentiary burden on plaintiffs in cases alleging exclusionary

\footnotetext{
${ }^{14}$ For one of the oft-cited illustrations of this set of arguments, see Frank H. Easterbrook, The Limits of Antitrust, 63 Tex. L. Rev. 1, 2-3 (1984). For a criticism of its approach, see Oliver E. Williamson, Delimiting Antitrust, 76 Geo. L.J. 271, 281-89 (1987). For a recent reconsideration of one of Easterbrook's foundation premises, that the consequences of false positives will be systematically more harmful than those of false negatives, see Thomas A. Lambert, The Limits of Antitrust in the 21st Century, (Univ. of Mo. Sch. of Law Legal Studies Research Paper Series, Research Paper No. 2020-06, 2020), https://papers.ssrn.com/sol3/papers.cfm?abstract_id=3533549 [https://perma.cc/CAH9-UBPJ] (discussing how Easterbrook's argument that antitrust should be calibrated to minimize error costs was sound, but subsequent scholarship has undermined his specific assumption with regard to the relative harm of false positives and false negatives).

${ }^{15}$ See Jonathan B. Baker, Taking the Error Out of 'Error Cost' Analysis: What's Wrong with Antitrust's Right, 80 Antitrust L.J. 1, 6 (2015) (“Contemporary antitrust conservatives have relied on the error cost framework to advocate various antitrust rules that would place a 'thumb on the scales' in favor of permitting firms to engage in much of the conduct that Judge Bork perceived as beneficial.").

${ }^{16}$ See, e.g., Verizon Commc'ns Inc. v. Law Offices of Curtis V. Trinko, LLP, 540 U.S. 398, 414 (2004) ("Mistaken inferences and the resulting false condemnations 'are especially costly, because they chill the very conduct the antitrust laws are designed to protect.' . . The cost of false positives counsels against an undue expansion of \$2 liability.") (quoting Matsushita Elec. Indus. Co. v. Zenith Radio Corp., 475 U.S. 574, 594 (1986)); Ball Mem’l Hosp., Inc. v. Mutual Hosp. Ins., 784 F.2d 1325, 1333 (7th Cir. 1986) ("A mistaken grant of an injunction may elevate this price, harming the consumers that antitrust laws are designed to protect.").
} 
conduct, which included a requirement of more economic evidence to support competitive harm allegations. $^{17}$

Many of the assumptions that guided this generation-long retrenchment of antitrust rules were mistaken, and advances in the law and in economic analysis have rendered them anachronistic. This is especially the case with respect to exclusionary conduct. ${ }^{18}$ Professors Krattenmaker and Salop showed that foreclosure conduct is not illusory and can lead to harm to competition by raising the costs of competitors and allowing the perpetrator to achieve or maintain monopoly power. ${ }^{19}$ Professor Kaplow and others showed the errors in the claim that exclusionary vertical restraints could not be used to extend or maintain monopoly power. ${ }^{20}$

As Professor Jonathan Baker has observed, rote invocation of error cost analysis can itself produce errors, particularly with respect to exclusionary conduct. ${ }^{21}$ Continued reliance on

${ }^{17}$ See, e.g., Posner, Exclusionary Practices, supra note 12; see also Robert H. Bork, The Antitrust Paradox 134-60 (1978) (advocating more demanding standards for demonstrating injury to competition).

${ }^{18}$ See generally Philippe Aghion \& Patrick Bolton, Contracts as a Barrier to Entry, 77 Am. Econ. Rev. 388 (1987); B. Douglas Bernheim \& Michael D. Whinston, Exclusive Dealing, 106 J. Pol. Econ. 64 (1998); Thomas G. Krattenmaker \& Steven C. Salop, Anticompetitive Exclusion: Raising Rivals' Costs to Achieve Power over Price, 96 Yale L.J. 209 (1986); Eric B. Rasmusen et al., Naked Exclusion, 81 Am. Econ. Rev. 1137 (1991); Michael H. Riordan \& Steven C. Salop, Evaluating Vertical Mergers: A Post-Chicago Approach, 63 Antitrust L.J. 513 (1995); Michael D. Whinston, Tying, Foreclosure, and Exclusion, 80 Am. Econ. Rev. 837 (1990).

${ }^{19}$ Krattenmaker \& Salop, supra note 18, at 230-31 (explaining valid foreclosure theories). ${ }^{20}$ See, e.g., Einer Elhauge, Tying, Bundled Discounts, and the Death of the Single Monopoly Profit Theory, 123 Harv. L. Rev. 397, 400-01 (2009) (explaining that absent restrictive assumptions, tying can increase monopoly profits absent efficiencies); Louis Kaplow, Extension of Monopoly Power Through Leverage, 85 Colum. L. Rev. 515 (1985) (explaining the limited applicability of the single monopoly profit theory).

${ }^{21}$ See Baker, supra note 15, at 29-30, 37-38 ("To protect a robust, effective, and socially beneficial competition policy, antitrust policy must avoid the erroneous application of error cost analysis."); see also Jonathan B. Baker, The Antitrust Paradigm: Restoring a Competitive 
what are now exaggerated fears of "false positives," and failure adequately to consider the harm from "false negatives," have led courts to impose excessive demands of proof on plaintiffs that belie both established procedural norms and sound economic analysis. ${ }^{22}$ This does not result in more reasonable antitrust standards, but instead results in an embedded ideological preference for non-intervention and a "thumb on the scales" 23 that creates a tendency toward false negatives, particularly in modern markets characterized by economies of scale and network effects. ${ }^{24}$ Indeed, the effect goes well beyond a "thumb on the scales," because it effectively shifts the default presumption from neutral to pro-defense. There are also excessive administrative costs, as ever "more" evidence is demanded, without regard for its cost or whether it is likely to significantly improve the accuracy of decisions.

In this article, we build on this prior work to explain how these erroneous assumptions about markets, institutions, and conduct have distorted the antitrust decision-making process and produced an excessive risk of false negatives in exclusionary conduct cases involving firms

Economy 73-77 (2019) (discussing the relationship of error-cost analysis to legal presumptions). Cf. Margaret C. Levenstein \& Valerie Y. Suslow, How Do Cartels Use Vertical Restraints? Horizontal and Vertical Working in Tandem, 83 Antitrust L.J. 15 (2020) (analyzing evidence that cartels use vertical restraints to facilitate horizontal collusion).

${ }^{22}$ A recent and potent example is the Supreme Court's decision in Ohio v. Am. Express Co., 138 S. Ct. 2274, 2284-88 (2018) (denigrating the role of direct evidence of competitive harm and shifting to the plaintiff the burden to disprove the sufficiency of the defendant's proffered justifications for its conduct).

${ }^{23}$ See Baker, supra note 15 , at 6.

${ }^{24}$ Economies of scale occur when a firm has lower average costs at higher levels of output.

Dennis W. Carlton \& Jeffrey M. Perloff, Modern Industrial Organization 36 (4th ed. 2005). Network effects occur when customers perceive product quality as higher when other customers purchase the product, for example, in the case of social media. See Carl Shapiro \& Hal R. Varian, Information Rules: A Strategic Guide to the Network Economy 184 (1999); Jeffrey Rohlfs, A Theory of Interdependent Demand for a Communications Service, 5 Bell J. Econ. \& Mgmt. Sci. 16 (1974). 
attempting to achieve, maintain, or enhance dominance or substantial market power. To redress this imbalance, we integrate modern economic analyses and the teachings of decision theory with the foundational conventions of antitrust law; these conventions have long relied on probability, presumptions, and reasonable inferences to provide effective means for evaluating competitive effects and resolving antitrust claims.

In Part I, we review the essential role that probability, presumptions, and inferences have played in shaping antitrust law's approach to defining evidentiary burdens. In Part II, we briefly explain the role decision theory should play in designing antitrust rules in the context of current case law and economic learning, and critically examine the Chicago-School critiques of 1960s antitrust and explain why their relevance is much reduced today. In Part III, we propose a series of guiding principles and advocate for easing of the burdens placed on plaintiffs to establish anticompetitive harm. We propose eliminating continued reliance on the unwarranted assumptions that have raised the plaintiff's burden in exclusionary conduct cases and tipped the litigation scales in favor of defendants and provide suggestions for how procompetitive presumptions might be more narrowly tailored.

\section{The Rule of Reason, Competitive Harm, and The Role of Probability, Inference, and Presumption}

\section{A. The Origins of the Rule of Reason}

Since its emergence in $\underline{\text { Standard Oil }},{ }^{25}$ the rule of reason has been rooted in probability, not certainty. ${ }^{26}$ The Supreme Court explained that conduct could be deemed "unreasonably

\footnotetext{
${ }^{25}$ Standard Oil Co. of N.J. v. United States, 221 U.S. 1, 61-62 (1911).
} 
restrictive of competitive conditions" if it "were of such a character as to give rise to the inference or presumption" that it was "restraining the free flow of commerce and tending to bring about the evils, such as enhancement of prices, which were considered to be against public policy. ${ }^{27}$ Seven years later, the Court again emphasized the probabilistic nature of judgments under the rule of reason in Board of Trade of Chicago. ${ }^{28}$ In Justice Brandeis's statement of the rule of reason, he explained that the court "must ordinarily consider . . the nature of the restraint and its effect, actual or probable. ${ }^{, 29}$

From these two pillars, the modern rule of reason with its focus on competitive effects later developed in National Society of Professional Engineers ${ }^{30}$ and National Collegiate Athletic

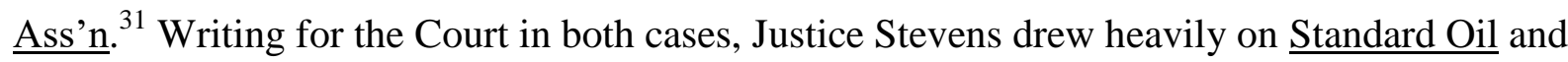
Chicago Board of Trade, synthesizing the key elements of presumption, inference, and

${ }^{26}$ See United States v. Microsoft Corp., 253 F.3d 34, 59 (D.C. Cir. 2001) (explaining that the Supreme Court in Standard Oil used the "rule of reason" to "describe the proper inquiry under both" Section 1 and 2 of the Sherman Act); Baker \& Gavil, supra note 10 (same); see also Steven C. Salop \& R. Craig Romaine, Preserving Monopoly: Economic Analysis, Legal Standards, and Microsoft, 7 Geo. Mason L. Rev. 617, 647-48, 652 (1999) (suggesting the application of Section 1's anticompetitive effects test to Microsoft's conduct under Section 2).

${ }^{27}$ Standard Oil, 221 U.S. at 58 (emphasis added). The Court also noted that the use of "presumption[s]" in interpreting and applying the Sherman Act was rooted in the common law, on which its core prohibitions were modeled. Id. at 27, 58.

${ }^{28}$ Bd. of Trade of Chi. v. United States (Chicago Board of Trade), 246 U.S. 231, 238 (1918).

${ }^{29} \underline{\text { Id. at }} 238$ (emphasis added); see also Am. Needle, Inc. v. Nat'1 Football League, 560 U.S. 183, 203 n. 10 (2010) ("Justice Brandeis provided the classic formulation of the Rule of Reason in Board of Trade of Chicago v. United States ....”).

${ }^{30}$ Nat'1 Soc'y of Prof'1 Eng'rs v. United States, 435 U.S. 679 (1978). Professional Engineers also emphasized that the rule of reason focuses on competitive effects. See $\underline{i d}$. at 692 ("[T]he purpose of the analysis is to form a judgment about the competitive significance of the restraint .....”);

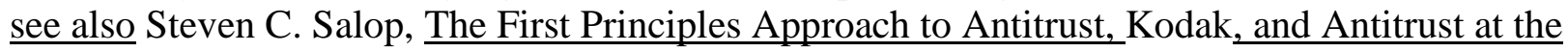
Millennium, 68 Antitrust L.J. 187, 188 (2000) (advocating a "first principles" approach to evaluating market power and anticompetitive effects).

${ }^{31}$ Nat'l Collegiate Athletic Ass'n v. Bd. of Regents of the Univ. of Okla., 468 U.S. 85 (1984). 
probability. He explained that unreasonableness could be based on either "the nature or character of the contracts, or ... on surrounding circumstances giving rise to the inference or presumption that they were intended to restrain trade and enhance prices." ${ }^{, 32}$ Probabilistic assessments of likely competitive harm also are the basis of the "per se rule," an application of the rule of reason that irrebuttably presumes conduct will restrain competition unreasonably. ${ }^{33}$

Although the rule of reason has evolved mainly in the context of Section 1 horizontal restraints law, this learning applies equally to exclusionary conduct cases under both Sections 1 and 2. The burden-shifting rule of reason has been used in concerted exclusionary conduct cases like $\underline{\text { Visa }}^{34}$ and RealComp II ${ }^{35}$ It also has been used to structure the analysis in several leading Section 2 cases involving single firm conduct, including Microsoft $,{ }^{36} \underline{\mathrm{McWane}},{ }^{37}$ and $\underline{\mathrm{ZF}}$

${ }^{32}$ Prof'l Eng'rs, 435 U.S. at 690 (emphasis added).

${ }^{33}$ See, e.g., United States v. Socony-Vacuum Oil Co., 310 U.S. 150, 226 n.59 (1940) (noting that price-fixing agreements are "banned because of their actual or potential threat" to competition); N. Pac. Ry. v. United States, 356 U.S. 1, 5 (1958) ("[A]greements [highly likely to be anticompetitive] are conclusively presumed to be unreasonable and therefore illegal without elaborate inquiry as to the precise harm they have caused or the business excuse for their use."). ${ }^{34}$ United States v. Visa U.S.A., Inc., 344 F.3d 229, 238, 240 (2d Cir. 2003) (finding it unlawful under Section 1 for Visa-member banks collectively to agree that they would not issue competing American Express or Discover cards).

${ }^{35}$ Realcomp II, Ltd. v. FTC, 635 F.3d 815, 824-25 (6th Cir. 2011) (determining that it is unlawful under Section 1 for members of a multiple listing service to impede consumer access to information about non-traditional real estate services offered by on-line brokers).

${ }^{36}$ United States v. Microsoft Corp., 253 F.3d 34, $58-59$ (D.C. Cir. 2001); see also Viamedia, Inc. v. Comcast Corp., 951 F.3d 429, 463-64 (7th Cir. 2020) (applying Microsoft's burden-shifting framework under Section 2).

${ }^{37}$ McWane, Inc. v. FTC, 783 F.3d 814, 833 (11th Cir. 2015). 
Meritor. ${ }^{38}$ Indeed, Standard Oil involved exclusionary conduct and included claims under both Sections 1 and $2 .^{39}$

\section{B. Satisfying the Plaintiff's Burden of Production}

As the rule of reason evolved, this reliance on probabilistic assessments of likely harm remained one of its core characteristics. ${ }^{40}$ Per se prohibition was reserved for conduct with a very high probability of harm. In other cases, the level of scrutiny and the likelihood of liability were calibrated to the nature and strength of the evidence of probable harm, whether circumstantial or direct, as well as presumptions based on the nature of the restraint, experience and the overarching goals of the Sherman Act.

Presumptions have consistently played a role in antitrust law when the prediction of competitive harm is deemed sound and, in some cases, when combined with some limited market-specific analysis. ${ }^{41}$ NCAA, Indiana Federation of Dentists, ${ }^{42}$ and $\underline{\text { California Dental }}{ }^{43}$ further developed that long-standing role, clarifying the respective burdens of the parties to antitrust litigation. A plaintiff can meet its burden of production through a rebuttable

${ }^{38}$ ZF Meritor, LLC v. Eaton Corp., 696 F.3d 254, 281 (3d Cir. 2012).

${ }^{39}$ Standard Oil Co. of N.J. v. United States, 221 U.S. 1, $72-74$ (1911).

${ }^{40}$ See, e.g., Broad. Music, Inc. v. CBS, Inc., 441 U.S. 1, 19-20 (1979) (finding that the "blanket license" utilized by ASCAP and BMI did not warrant per se condemnation because the practice was not a "naked restraint" that "always or almost always" tended to unreasonably restrain competition); Cont'l T.V., Inc. v. GTE Sylvania Inc., 433 U.S. 36, 49-50, 50 n.16 (1977) (holding that the use of a per se approach to the rule of reason should be limited to conduct that is "manifestly anticompetitive" and noting that "[ $\mathrm{t}] \mathrm{he}$ probability that anticompetitive consequences will result from a practice and the severity of those consequences must be balanced against its pro-competitive consequences").

${ }^{41}$ See, e.g., Nat'1 Soc'y of Prof'1 Eng'rs v. United States, 435 U.S. 679, $693-94$ (1978); Polygram Holding, Inc. v. FTC, 416 F.3d 29, 37 (D.C. Cir. 2005).

${ }^{42}$ FTC v. Ind. Fed'n of Dentists, 476 U.S. 447 (1986).

${ }^{43}$ Cal. Dental Ass'n v. FTC, 526 U.S. 756 (1999). 
anticompetitive presumption when economic theory predicts a relatively high or "obvious"

probability of competitive harm. ${ }^{44}$ Courts also recognized that a plaintiff could meet its burden of production for competitive harm with a "double inference:" 45 courts could infer market power from high market shares and other factors in a defined market; combining this inference with conduct that has a tendency to be anticompetitive, competitive harm could then be inferred-precisely because that tendency increases in the presence of market power. ${ }^{46}$ Finally, the Supreme Court has also recognized that when direct evidence of probable anticompetitive effect is proffered, neither presumption nor inference is required. ${ }^{47}$

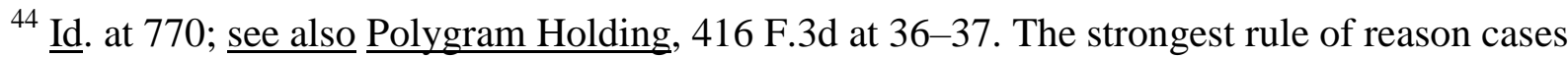
from the perspective of the plaintiff will include both direct and circumstantial evidence of harm. See, e.g., Realcomp II, Ltd. v. FTC, 635 F.3d 815, 827-34 (6th Cir. 2011) (evaluating both direct and circumstantial evidence of competitive harm under the rule of reason). The Supreme Court's decisions in NCAA and Indiana Federation of Dentists were part of a larger movement to alleviate the burden of production (and proof) on plaintiffs in cases involving relatively more obvious anticompetitive conduct. See Gavil, supra note 11, at 755-57.

${ }^{45}$ For an explanation of this "double inference" method of establishing competitive harm, see Andrew I. Gavil et al., Antitrust Law in Perspective: Cases, Concepts and Problems in Competition Policy 544-45 (3d ed. 2017).
}

${ }^{46}$ See, e.g., Realcomp II, 635 F.3d at 823 ("Realcomp's substantial market power, combined with the likely anticompetitive tendencies of its policies, rendered the policies unreasonable due to their likely anticompetitive effects.").

${ }^{47}$ Nat'l Collegiate Athletic Ass'n v. Bd. of Regents of the Univ. of Okla., 468 U.S. 85, 109 (1984) ("[W] $[\mathrm{W}$ n there is an agreement not to compete in terms of price or output, "no elaborate industry analysis is required to demonstrate the anticompetitive character of such an agreement."') (quoting Nat'l Soc'y of Prof'1 Eng'rs v. United States, 435 U.S. 679, 692 (1978); Ind. Fed'n of Dentists, 476 U.S. at 460-61 (““[P]roof of actual detrimental effects, such as a reduction of output,' can obviate the need for an inquiry into market power, which is but a 'surrogate for detrimental effects."') (quoting 7 Phillip E. Areeda, Antitrust Law II 1511, at 429 (3d ed. 1986)). 
In evidentiary terms, direct evidence of probable competitive harm can eliminate the need to rely on circumstantial evidence, and hence either presumption or inference. ${ }^{48}$ This is not, however, a short cut or "quick look" that somehow avoids a showing of market power. ${ }^{49}$ Quite to the contrary, when direct evidence of competitive harm is available, market power also has been shown. ${ }^{50}$ As understood by the lower courts, the Supreme Court did not suggest that such direct proof was a requirement of rule of reason analysis, but rather that such proof met the plaintiff's burden of production and hence eliminated the necessity of reliance on circumstantial evidence. ${ }^{51}$

Indeed, direct evidence of anticompetitive effects on price and output also can be sufficient to rebut a defendant's efficiency justifications. When direct evidence of anticompetitive effects has been shown (and not undermined), the plaintiff in effect has preemptively shown that any procompetitive benefits were inadequate to eliminate the demonstrated anticompetitive effects in the market. ${ }^{52}$

${ }^{48}$ Similarly, courts in conspiracy cases do not rely on "plus factor" analysis to infer agreement when there is direct evidence of agreement, such as bylaws, a contract, or communications revealing a conspiracy. See, e.g., In re High Fructose Corn Syrup Antitrust Litig., 295 F.3d 651, 661-62 (7th Cir. 2002) (explaining that direct evidence in Section 1 conspiracy is "evidence tantamount to an acknowledgment of guilt").

${ }^{49}$ Assembling direct evidence of harm is not necessarily "quick," relative to the circumstantial route. Obtaining direct proof may require significant investigation and evidence gathering. Direct proof also is likely to involve different economic methods, although there may be overlap with direct evidence of market power.

${ }^{50}$ Ind. Fed'n of Dentists, 476 U.S. at 460-61; see also supra note 44 and accompanying text; infra note 114 and accompanying text.

${ }^{51}$ See, e.g., Polygram Holding, Inc. v. FTC, 416 F.3d 29, 36 (D.C. Cir. 2005) (interpreting Supreme Court decisions as rejecting the argument that a quick look approach is only available when evidence of actual harm is proffered).

${ }^{52}$ See, e.g. Ind. Fed'n of Dentists, 476 U.S. at 461 (“'[T]he finding of actual, sustained adverse effects on competition in those areas where IFD dentists predominated, viewed in light of the reality that markets for dental services tend to be relatively localized, is legally sufficient to 


\section{The "Enquiry Meet for the Case"}

In moving away from reliance on bright line approaches, the courts continued to use probability assessments to apply the rule of reason flexibly, depending on the strength of the evidence presented by the parties and by recognizing appropriate presumptions. A more precise statement of the "per se rule," for example, is "per se unreasonableness"--an application of the rule of reason that involves an irrebuttable presumption that the conduct is highly likely to unreasonably restrain competition. ${ }^{53}$ Similarly, what has been labelled the "quick look" can be understood as courts utilizing a rebuttable presumption when the probability of competitive harm is relatively high, albeit not as high as with per se unreasonableness.

This approach reached fruition in California Dental. ${ }^{54}$ The Supreme Court made it clear that the rule of reason is a sliding-scale and that evidence of anticompetitive effects varies and must be evaluated in the context of each case. ${ }^{55}$ The strength of any presumption of competitive harm affects the burden on the plaintiff to undertake market analysis. It also correspondingly affects the defendant's evidentiary burden to rebut evidence or presumption of harm. This is the "enquiry meet for the case." ${ }^{56}$ It synthesized the Court's previous decisions describing the rule of

support a finding that the challenged restraint was unreasonable even in the absence of elaborate market analysis.").

53 This view was not entirely new, as the Court had observed in the late 1950s that what was being referred to as the "per se rule" was a "principle of per se unreasonableness." N. Pac. Ry. v. United States, 356 U.S. 1, 5 (1958).

${ }^{54}$ Cal. Dental Ass'n v. FTC, 526 U.S. 756, 758 (1999).

55 Id. at 779-81; see also FTC v. Actavis, Inc., 570 U.S. 136, 159-60 (2013).

${ }^{56}$ Cal. Dental Ass'n, 526 U.S. at 781. 
reason inquiry as focused on the probability--on tendencies--of competitive harm. ${ }^{57}$ But as the 54 division in the Court illustrated, that formulation leaves room for disagreements about the quantity and quality of evidence needed to support an inference of probable competitive harm.

\section{Developing New Presumptions}

The rule of reason and its presumptions should continue to evolve over time as economic learning advances and courts gain further experience with industries and firm practices. The decisions of $\underline{\text { Leegin }}^{58}$ and $\underline{\text { Actavis }}^{59}$ invited lower courts to consider the adoption of appropriate presumptions based on experience in applying the rule of reason (respectively) to intrabrand vertical price agreements and pay-for-delay cases. ${ }^{60}$ In this regard, after discussing the decision theory framework and examining certain assumptions made by conservative commentators and the presumptions that flow from those assumptions, we propose principles to guide the evolution of the rule of reason for exclusionary conduct in today's modern marketplace. Our goal is to

${ }^{57}$ This approach also aligned the rule of reason as applied under Section 1 with the structured approaches that the Court, and the lower courts, had been developing in other areas of antitrust law, including monopolization under Section 2 and mergers under Section 7 of the Clayton Act. See Baker \& Gavil, supra note 10.

${ }^{58}$ Leegin Creative Leather Prods., Inc. v. PSKS, Inc., 551 U.S. 877, 898-99 (2007) ("Courts can, for example, devise rules over time for offering proof, or even presumptions where justified, to make the rule of reason a fair and efficient way to prohibit anticompetitive restraints and to promote procompetitive ones.") (emphasis added).

${ }^{59}$ Actavis, 570 U.S. at 159-60.

${ }^{60}$ For a definition of "intrabrand competition," see Cont'1 T.V., Inc. v. GTE Sylvania Inc., 433 U.S. 36, 52 n.19 (1977) ("Interbrand competition is the competition among the manufacturers of the same generic product--television sets in this case--and is the primary concern of antitrust law. ... In contrast, intrabrand competition is the competition between the distributors-wholesale or retail--of the product of a particular manufacturer."). "Pay-for-delay" agreements, also referred to as "reverse payment" agreements, are explained and examined in FTC v. Actavis, Inc., 570 U.S. 136 (2013). 
avoid the excessive false negatives that are highly likely to flow from unduly permissive antitrust rules grounded in outdated non-interventionist presumptions and assumptions.

\section{II: Achieving a Sound Decision-Theoretic Approach to Antitrust Legal Standards for Exclusionary Conduct}

\section{A. Decision Theory and Probabilistic Competitive Harm}

It has been recognized for decades that decision theory is useful for understanding and formulating legal standards. ${ }^{61}$ Making legal decisions based on probability, inferences, and presumptions is consistent with a decision-theoretic approach to legal rules. Decision theory provides a methodology for information-gathering and decision-making when outcomes are uncertain, information is inherently imperfect, and information is costly to obtain. This methodology is a rational process in which a decision-maker begins with initial beliefs (i.e., presumptions) based on prior knowledge and then gathers additional information (i.e., evidence) to supplement the presumption in order to make a better, more accurate decision. ${ }^{62}$

Decision theory recognizes that some erroneous decisions are inevitable because it is not economical, or even possible, to achieve perfect information. Even if the evidence suggests that

${ }^{61}$ There is a large literature on the application of decision theory to antitrust. See, e.g., C. Frederick Beckner III \& Steven C. Salop, Decision Theory and Antitrust Rules, 67 Antitrust L.J. 41 (1999); Isaac Ehrlich \& Richard A. Posner, An Economic Analysis of Legal Rulemaking, 3 J. Legal Stud. 257 (1974). For further discussion of its application in assigning burdens of proof, see Edward K. Cheng, Reconceptualizing the Burden of Proof, 122 Yale L.J. 1254 (2013); Louis Kaplow, Burden of Proof, 121 Yale L.J. 738 (2012).

${ }^{62}$ See, e.g., John Kaplan, Decision Theory and the Factfinding Process, 20 Stan. L. Rev. 1065, 1084-86 (1968); Morris H. DeGroot, Optimal Statistical Decisions 135-40 (1970); Howard Raiffa, Decision Analysis: Introductory Lectures on Choices Under Uncertainty 27-33 (1968). In the language of Bayesian probability theory, the decision-maker begins with a "prior" probability, gathers information, and then forms a "posterior" probability by rationally combining the prior probability and the information. Here we are not using "presumption" in the formal legal sense, but as a synonym for "assumptions" or "priors." 
the conduct in a particular case is beneficial, the conduct actually may be harmful, or vice versa. Formulating an optimal legal standard would involve balancing to the extent possible the expected consumer welfare harm from "false positive" errors (i.e., erroneously prohibiting beneficial conduct) versus "false negative" errors (i.e., erroneously permitting harmful conduct). Analysis of error costs would require information on the incidence and consequences of error. The analysis also would take into account the impact of the legal rule on deterrence, that is, on future participants' choice of conduct in light of the legal standard. ${ }^{63}$ It also could take into account the cost of the administrative process, including the cost of delay.

Presumptions also play a key role in setting evidentiary burdens under the rule of reason. The recognition of a presumption is a question of law. The court would identify and gauge the strength of its initial economic presumption regarding the likely competitive impact of the conduct. This presumption would be rationally based on logic, experience, and economic evidence about the industry and the category of conduct. ${ }^{64}$ The presumption regarding the

${ }^{63}$ Deterrence effects are distinguishable from the issue of judicial errors for a given legal standard. For example, a rule of per se legality would be easy to administer and would not lead a district court to issue erroneous "false convictions." But such a legal standard might not be optimal because it would not deter any anticompetitive conduct in that category. For discussion of deterrence, see Ronald J. Allen \& Alex Stein, Evidence, Probability, and the Burden of Proof, 55 Ariz. L. Rev. 557, 580, 593 (2013). False positives as well as false negatives tend to lead to under-deterrence of anticompetitive conduct in some circumstances. See Steven C. Salop, Merger Settlement and Enforcement Policy for Optimal Deterrence and Maximum Welfare, 81 Fordham L. Rev. 2647, 2668-69, 2669 n.60 (2013) (explaining that compliance incentives decrease when the probability of error of either type increases).

${ }^{64}$ A key assumption of decision theory is that the initial presumptions of the court are rational and accurate. Confirmation bias involves (unconsciously) interpreting evidence as supporting one's prior views, which amounts to dysfunctional Bayesian inference. For one survey, see Raymond S. Nickerson, Confirmation Bias: A Ubiquitous Phenomenon in Many Guises, 2 Rev. Gen. Psychol. 175, 211 (1998) (“Our natural tendency seems to be to look for evidence that is directly supportive of hypotheses we favor and even, in some instances, of those we are entertaining but about which we are indifferent."). 
category of conduct could be anticompetitive, procompetitive, or neutral (i.e., equally likely to be anticompetitive or procompetitive). The strength of the presumption would vary with the degree of variation in the likely effects of the conduct. Because any single district court is likely to have very limited information about the probable categorical effects of conduct, appellate courts and the Supreme Court are better positioned to make judgments about presumptions. The recognition and formulation of presumptions, therefore, should be left to appellate courts, the Supreme Court, and Congress, with district courts constrained to their role as implementers.

A legal standard can be characterized as the combination of the evidentiary preconditions that will trigger a presumption and an evidentiary standard to rebut the presumption. ${ }^{65}$ The optimal evidentiary standard would balance the direction and strength of the presumption with the reliability and cost of the available evidence. For example, suppose that the presumption is that some category of conduct is more likely harmful. ${ }^{66} \mathrm{~A}$ court could reflect this presumption (i) by treating the presumption as sufficient to satisfy the plaintiff's initial burden, or (ii) by placing a relatively low burden of production of case-specific evidence on the plaintiff. The court also

\footnotetext{
${ }^{65}$ These evidentiary rebuttal standards would include the respective burdens of pleading, production, and proof for plaintiffs and defendants.

${ }^{66}$ Such a presumption might not be as simple as "conduct A is so likely to be anticompetitive that we presume it will be," as is the case for some per se prohibitions. It might instead be that "conduct A, in the presence of facts B, C, and D, is highly likely to be anticompetitive." Such qualified presumptions have been used by the Supreme Court in connection with certain kinds of group boycotts, see Nw. Wholesale Stationers, Inc. v. Pac. Stationery \& Printing Co., 472 U.S. 284, 295-97 (1985) ("Unless the cooperative possesses market power or exclusive access to an element essential to effective competition, the conclusion that expulsion is virtually always likely to have an anticompetitive effect is not warranted."), and tying arrangements, see Jefferson Par. Hosp. Dist. No. 2 v. Hyde, 466 U.S. 2, 12-16 (1984) ("[W]e have condemned tying arrangements when the seller has some special ability--usually called 'market power'--to force a purchaser to do something that he would not do in a competitive market."). They similarly are used in merger law, where the anticompetitive presumption depends on the level of concentration and market shares of the merging firms as well as the change in concentration that the proposed merger will bring about. United States v. Phila. Nat'l. Bank, 374 U.S. 321, 363 (1963).
} 
might place a higher burden of production or even persuasion on the defendant to rebut the plaintiff's presumption and case-specific evidence. A stronger presumption and evidence of harm would raise the defendant's rebuttal burden. The plaintiff's burden of producing evidence of competitive harm analogously would be higher for presumptively procompetitive categories of conduct.

The cost of information also suggests the potential benefits from a structured and sometimes truncated process. ${ }^{67}$ As we have noted, the term "per se illegality" describes an irrebuttable presumption of harm for certain categories of conduct. The FTC and some courts have used the term "inherently suspect," a term first used by the Supreme Court in the context of merger analysis, ${ }^{68}$ to describe conduct that warrants a strong, but rebuttable presumption of likely harm, given certain other conditions. ${ }^{69}$ In some cases, the presumption may be insufficient by itself to shift the burden, but might have a supporting role along with other case-specific

${ }^{67}$ See FTC v. Superior Court Trial Lawyers Ass'n, 493 U.S. 411, 434 (1990) (“[T]he justification for these per se rules is rooted in administrative convenience.”); N. Pac. Ry. v. United States, 356 U.S. 1, 5 (1958) (noting that per se presumption "avoids the necessity for an incredibly complicated and prolonged economic investigation into the entire history of the industry involved, as well as related industries").

${ }^{68}$ Phila. Nat'l Bank, 374 U.S. at 363 (explaining that the use of a presumption in the context of merger analysis "lightens the burden of proving illegality only with respect to mergers whose size makes them inherently suspect in light of Congress' design in $\S 7$ to prevent undue concentration").

${ }^{69}$ See N. Tex. Specialty Physicians v. FTC, 528 F.3d 346, 358-61 (5th Cir. 2008) (applying an inherently suspect “"quick-look' rule-of-reason analysis” to a case of alleged horizontal pricefixing activities); Polygram Holding, Inc. v. FTC, 416 F.3d 29, 32-33 (D.C. Cir. 2005) ("[C]onduct that 'appears likely, absent an efficiency justification, to restrict competition and decrease output'--is to be presumed unreasonable." (quoting Polygram Holding, Inc. Docket No. 9298, 22-24 (F.T.C. July 28, 2003) (Opinion of the Commission), https://www.ftc.gov/sites/default/files/documents/cases/2003/07/polygramopinion.pdf)); In re Detroit Auto Dealers Ass'n, 955 F.2d 457, 459, 470-71 (6th Cir. 1992) (applying the approach to auto dealerships charged with anti-competitive action in keeping their showrooms closed certain days of the week). 
evidence. Thus, this decision-theoretic approach can be used to interpret and extend the "sliding scale" approach to applying the rule of reason even in the absence of an anticompetitive presumption.

Under the rule of reason, it might be useful to limit the amount of information necessary to evaluate competitive effect. Demanding more information in some cases can lead to more errors or worsened deterrence. Certain evidence may not be reasonably available or will be unreliable because it (i) too often signals an erroneous conclusion, or (ii) is too likely subject to confusion, misinterpretation, or bias by the trial court or jury. ${ }^{70}$ Collecting and presenting additional information is not costless and may have diminishing returns and only marginal benefits, if any. ${ }^{71}$ Moreover, requiring additional evidence disadvantages the plaintiff, which has the initial burden and the ultimate burden of proof. It also can deter meritorious cases, leading to under-deterrence.

\section{B. The Chicago-School's Reliance on Decision Theory to Support its Critique of Antitrust}

Chicago-School commentators applied a decision-theoretic framework to argue that antitrust law as it existed in the 1960s tended towards false positives, including over-deterrence

\footnotetext{
${ }^{70}$ See Fed. R. Evid. 403 ("The court may exclude relevant evidence if its probative value is substantially outweighed by a danger of one or more of the following: unfair prejudice, confusing the issues, misleading the jury, undue delay, wasting time, or needlessly presenting cumulative evidence."); see also Fed. R. Evid. 702(c) (expert opinion testimony can be excluded if is not "the product of reliable principles and methods").

${ }^{71}$ The collection of evidence should be "proportional to the needs of the case," including "whether the burden or expense of the proposed discovery outweighs its likely benefit." Fed. R. Civ. P. 26(b)(1). See also Andrew I. Gavil, Burden of Proof in U.S. Antitrust Law, in 1 Issues in Competition Law and Policy 125, 129 (ABA Section of Antitrust Law 2008) ("the question would be whether the marginal contribution to accuracy of outcome (reduction of error) derived from additional process would be outweighed by the costs required to gather, present, and evaluate additional information.").
} 
of beneficial conduct. They attributed this tendency to a lack of appreciation for efficiency benefits of the allegedly anticompetitive conduct, undemanding burdens of proof on plaintiffs, bright line liability rules, and the limited competence and bias of antitrust decision-makers (i.e., agencies, courts, and juries) in evaluating competitive effects. These commentators also assumed that the costs of false positives far exceeded the costs of false negatives because any anticompetitive effects from under-enforcement (false negatives) would be dissipated by the selfcorrecting tendencies of markets, whereas any anticompetitive effects of over-enforcement (false positives) would prove durable due to the longevity of legal precedent. ${ }^{72}$

They were especially skeptical of anticompetitive concerns regarding exclusionary conduct. They suggested that complaining rivals were highly likely to be inefficient competitors, who were attempting to use antitrust to prevent more efficient larger firms from competing on the merits to the benefit of consumers. ${ }^{73}$ Intrabrand vertical restraints were assumed to be procompetitive in most cases and potential exclusionary effects were dismissed or ignored. ${ }^{74}$ Interbrand restraints, such as exclusive dealing, were assumed to be generally efficient, even if used by firms with substantial market power. ${ }^{75}$ Robert Bork argued that foreclosure was illusory

${ }^{72}$ See, e.g., Easterbrook, supra note 14, at 2. For a more recent example, see generally Murat C. Mungan \& Joshua Wright, Optimal Standards of Proof in Antitrust 3 (George Mason Univ. Law \& Econ. Research Paper Series, No. 19-20, 2019), https://ssrn.com/abstract=3428771 [https://perma.cc/DRX7-X5SB].

${ }^{73}$ See, e.g., William J. Baumol \& Janusz A. Ordover, Use of Antitrust to Subvert Competition, 28 J.L. \& Econ. 247, 248 (1985) (describing how firms seek antitrust protection from "the unpleasantness of effective competition"); Easterbrook, supra note 14, at 35 (cautioning courts to "treat suits by horizontal competitors with the utmost suspicion").

${ }^{74}$ See, e.g., Douglas H. Ginsburg, Vertical Restraints: De Facto Legality Under the Rule of Reason, 60 Antitrust L.J. 67 (1991); Richard A. Posner, The Next Step in the Antitrust Treatment of Restricted Distribution: Per Se Legality, 48 U. Chi. L. Rev. 6 (1981).

${ }^{75}$ See, e.g., Benjamin Klein \& Andres V. Lerner, The Expanded Economics of Free-Riding: How Exclusive Dealing Prevents Free-Riding and Creates Undivided Loyalty, 74 Antitrust L.J. 
and could not harm competition because there was only a single monopoly profit. ${ }^{76}$

Commentators have also suggested that monopolists drive innovation. ${ }^{77}$

These criticisms and the proposed solution of more permissive antitrust rules and higher burdens of proof have been highly influential. Intrabrand vertical restraints are no longer condemned per se as is also true for most exclusionary group boycotts. The per se prohibition of tying is teetering. ${ }^{78}$ Encouraged by $\underline{\text { Matsushita }}^{79}$ and Twombly, ${ }^{80}$ motions to dismiss and for summary judgment are now more commonly made. Courts and agencies also have become more

473, 519 (2007) (describing circumstances in which exclusive dealing can be deemed efficient); Benjamin Klein \& Kevin M. Murphy, Exclusive Dealing Intensifies Competition for Distribution, 75 Antitrust L.J. 433, 435 (2008) (explaining how exclusive dealing can mitigate issues with contracting directly with retailers); Howard P. Marvel, Exclusive Dealing, 25 J.L \& Econ. 1, 3-4 (1982) ("The most commonly expressed view of exclusive dealing in the literature portrays it as a device to obtain increased dealer promotional effort.").

${ }^{76}$ Robert H. Bork, The Antitrust Paradox 137-38, 140, 372-73 (1978).

${ }^{77}$ For a discussion and critique of this argument, see Baker, supra note 15, at 13-14 ("This 'dynamic competition' defense of concentrated markets, or of conduct allowing firms to create or maintain market power, is unconvincing because it ignores several important ways that greater competition enhances incentives to innovate."); see also Dennis W. Carlton \& Ken Heyer, Extraction v. Extension: The Basis for Formulating Antitrust Policy Towards Single-Firm Conduct, 4 Competition Pol'y Int'l 285, 290-92 (2008).

78 "Tying" involves the sale of a product or service only on the condition that the buyer also purchase a second, unwanted product or service. Traditionally the practice was treated as per se unlawful when certain conditions were also present. See Jefferson Par. Hosp. Dist. No. 2 v. Hyde, 466 U.S. 2, 15-16 (1984) ("Per se condemnation-condemnation without inquiry into actual market conditions - is only appropriate if the existence of forcing is probable. Thus, application of the per se rule focuses on the probability of anticompetitive consequences.") (footnote omitted). ). But more recently courts have been reluctant to use the per se approach in other circumstances. See United States v. Microsoft Corp., 253 F.3d 34, 89-95 (D.C. Cir. 2001) (declining to apply per se approach to platform software).

${ }^{79}$ Matsushita Elec. Indus. Co. v. Zenith Radio Corp., 475 U.S. 574, 585-88 (1986) (revitalizing the use of summary judgment in antitrust cases).

${ }^{80}$ Bell Atl. Corp. v. Twombly, 550 U.S. 544, 554-57 (2007) (raising the burden of pleading for plaintiffs to state a claim under Federal Rule 8(a)(2)). 
sophisticated in evaluating economic arguments. Economic testimony is now the norm and subject to Daubert challenges. ${ }^{81}$

The assumptions underlying these criticisms also have been very influential in producing a non-interventionist bias in the law. For example, in Brooke Group, the Court expressed skepticism that the cigarette oligopolists would be able to coordinate successfully after disciplining a price-cutting rival, despite evidence that they had coordinated historically. ${ }^{82}$ The single monopoly profit theory was treated as a broad guide in Justice O'Connor's concurrence in $\underline{\text { Jefferson Parish }}^{83}$ and subsequent opinions by Justices Breyer and Sotomayor when they were appellate judges, leading them to reach potentially erroneous conclusions about probable exclusionary effects. ${ }^{84}$ The Supreme Court's analysis in $\underline{\text { Trinko }}^{85}$ is partially based on the belief that monopolists are the main engines of future innovation and should be permitted to restrict competition to maintain their innovation incentives. ${ }^{86}$ Several courts concluded that exclusive

${ }^{81}$ See, e.g., In re Wholesale Grocery Prods. Antitrust Litig., 946 F.3d 995, 1000-03 (8th Cir. 2019) (finding that the district court did not abuse discretion in applying principles of Daubert and Federal Rule of Evidence 702 to exclude testimony of plaintiff's expert economist).

${ }^{82}$ Brooke Grp. Ltd. v. Brown \& Williamson Tobacco Corp., 509 U.S. 209, 232 (1993) ("[R]elying on tacit coordination among oligopolists as a means of recouping losses from predatory pricing is 'highly speculative"'). But see id. at 253-54 (Stevens, J., dissenting) (arguing that the evidence was sufficient to show the required "reasonable possibility" of harm to competition).

${ }^{83}$ Jefferson Par. Hosp. Dist. No. 2, 466 U.S. at 36 (O'Connor, J., concurring) ("The existence of a tied product normally does not increase the profit that the seller with market power can extract from sales of the tying product."), abrogated by Ill. Tool Works Inc. v. Indep. Ink, Inc., 547 U.S. 28 (2006).

${ }^{84}$ E \& L Consulting, Ltd. v. Doman Indus. Ltd., 472 F.3d 23, 30 (2d Cir. 2006) (Winter, Pooler, and Sotomayor, JJ.); Town of Concord v. Bos. Edison Co., 915 F.2d 17, 23-24 (1st Cir. 1990) (Breyer, C.J.).

${ }^{85}$ Verizon Commc'ns Inc. v. Law Offices of Curtis V. Trinko, LLP, 540 U.S. 398 (2004).

${ }^{86}$ Id. at 407 ("The opportunity to charge monopoly prices--at least for a short period--is what attracts 'business acumen' in the first place; it induces risk taking that produces innovation and 
dealing contracts with durations of one year or less should be treated as presumptively lawful on the ground that they are easily contestable. ${ }^{87}$

C. The Errors and Inapplicability of the Chicago-School Prescriptions for Current Antitrust $\underline{\text { Analysis }}$

While the Chicago-School's analysis provided useful criticisms of 1960s legal standards, they have gone too far in various ways. Modern economic analysis has now invalidated many of their criticisms. ${ }^{88}$ The overarching assumption that false positives are more concerning than false negatives because of rapid market self-correction is undermined by the observation that longlasting cartels with a significant number of participants have been observed. Market dominance can be quite durable, in some instances lasting for decades. Barriers to entry, specifically including barriers resulting from the incumbent monopolist's exclusionary conduct, can prevent market self-correction. ${ }^{89}$

economic growth.”). For a critique of Trinko, see Andrew I. Gavil, Exclusionary Distribution Strategies by Dominant Firms: Striking a Better Balance, 72 Antitrust L.J. 3, 41-51 (2004) (" $[\mathrm{I}] \mathrm{t}$ is perhaps worth inquiring whether the presumed connection between the dream of monopoly and innovation is in fact warranted as a general proposition.").

${ }^{87}$ See, e.g., Roland Mach. Co. v. Dresser Indus., Inc., 749 F.2d 380, 395 (7th Cir. 1984) ("Exclusive-dealing contracts terminable in less than a year are presumptively lawful ...."). For a discussion of the relevant cases and the critique of this view, see Gavil, et al. supra note 45, at 1038-39.

${ }^{88}$ For an excellent catalogue of these assumptions as they relate both to markets and institutions, see Baker, supra note 15, at 8-36 (analyzing nine such "erroneous assumptions"); see also Jonathan B. Baker, Exclusion as a Core Competition Concern, 78 Antitrust L.J. 527, 528 (2013) ("Mainstream and progressive commentators also call collusion the central antitrust problem, although post-Chicago commentators tend more than most to take exclusionary conduct seriously.") (footnote omitted).

${ }^{89}$ See Baker, supra note 21, at 17 (citing evidence that cartels, oligopolies, and monopolies have been more durable than predicted by Chicago-School critics); $\underline{\text { see also Steven C. Salop, The }}$ Raising Rivals' Cost Foreclosure Paradigm, Conditional Pricing Practices, and the Flawed Incremental Price-Cost Test, 81 Antitrust L.J. 371, 391-92 (2017) (describing how foreclosure 
Chicagoans argued that competitor complaints were most likely motivated by the fear of increased competition, which has led to skepticism of such complaints, including a recommendation of denial of standing, ${ }^{90}$ and has been extended to promote ex ante credibility judgments of witnesses, both positive and negative. ${ }^{91}$ In fact, the interests of competitors whose costs are raised by exclusionary conduct are consistent with the interests of consumers whose prices are raised as a result. While antitrust protects "competition, not competitors," that does not mean that competitors' interests necessarily are opposed to consumer interests or that courts should categorically discount the fate of competitors. This oft-repeated refrain is especially selfserving and suspect when the conduct of a firm with substantial market power has the effect of excluding a rival that is the embodiment of market "self-correction."92

Modern analysis also has invalidated the Chicagoan critiques of exclusionary conduct by firms with substantial market power. The claim that anticompetitive exclusion would be unprofitable because there is only a single monopoly profit has been shown to be invalid except

can be used to thwart market-correcting entry). See also McWane, 783 F.3d at 838 (noting FTC's finding that McWane's conduct harmed competition by making effective entry more costly and difficult).

${ }^{90}$ Cargill, Inc. v. Monfort of Colo., Inc., 479 U.S. 104, 106, 122 (1986) (finding that the allegations of the nation's fifth-largest beef packing company about the results of a merger of the second and third largest beef packing companies were insufficient to show a threat of antitrust injury as a result of predatory pricing necessary to enjoin the merger under the Clayton Act); see also Easterbrook, supra note 14, at 33-39.

${ }^{91}$ Some courts have openly questioned the credibility of witnesses employed by the plaintiff as self-interested, yet credited, without similar scrutiny, the testimony of the obviously selfinterested parties defending their conduct. See, e.g., United States v. AT \& T Inc., 310 F. Supp. 3d 161, 227, 229-30 (D.D.C. 2018), aff'd sub nom. United States v. AT\&T, Inc., 916 F.3d 1029 (D.C. Cir. 2019).

${ }^{92}$ See, e.g., Spirit Airlines, Inc. v. Nw. Airlines, Inc., 431 F.3d 917, 951 (6th Cir. 2005) (“[I]n a concentrated market with very high barriers to entry, competition will not exist without competitors."). 
in one highly unrealistic set of market conditions. ${ }^{93}$ It also overlooks the fact that exclusionary conduct can insulate a firm with legitimately-achieved monopoly power from new competitive threats that might weaken or undo its market dominance. ${ }^{94}$ The idea that entrants can overcome exclusives simply by outbidding monopolists for needed inputs fails to recognize that entrants face disadvantages in bidding against monopolists that hold exclusives, even if the exclusives are only short-term. ${ }^{95}$ This is because a dominant firm typically has more profits to protect by maintaining its monopoly rather than facing a competitive market than an entrant can gain by achieving viability in a competitive market. ${ }^{96}$

Chicagoans similarly overlook a key fact about private antitrust litigation that flows from the asymmetric effects of competition on the profits of the incumbent monopolist versus an entrant or small competitor. Antitrust defendants typically have systematically higher litigation

${ }^{93}$ For a detailed exposition of these conditions, including examples of when the single monopoly profit theory would not hold, see Gavil et. al., supra note 45, at 959-65; see also Kaplow, supra note 20, at 515 ("There are a number of deficiencies in the analysis of recent commentators who have attempted to proclaim the death of leverage theory."); Krattenmaker \& Salop, supra note 18, at 224 ("Nor can one dismiss these claims of anticompetitive effect with the argument that there is only a single monopoly profit and that 'leverage' is impossible.").

${ }^{94}$ See Kaplow, supra note 20, at 520-21; Krattenmaker \& Salop, supra note 18, at 246. For a study on how the tying of complementary products can create monopolistic positions, see Dennis W. Carlton \& Michael Waldman, The Strategic Use of Tying to Preserve and Create Market Power in Evolving Industries, 33 RAND J. Econ. 194 (2002).

${ }^{95}$ See Salop, supra note 89, at 407-15 ("The predatory pricing paradigm and the conventional rationale for the [incremental price-cost] test assume that bidding for distributors or customers takes place on a level playing field. This assumption is generally not the case. A dominant incumbent firm has significant bidding advantages."). This mistake was evident in Judge Easterbrook's decision in Paddock Publ'ns, Inc. v. Chi. Tribune Co., 103 F.3d 42, 47 (7th Cir. 1996), where he concluded that a rival excluded by exclusive contracts should "try to outbid" the two dominant incumbents "in the marketplace, rather than to outmaneuver them in court."

${ }^{96}$ Salop, supra note 89, at 408-10. In addition, distributors' fears that the entrant will fail can become a self-fulfilling prophecy by leading them to accept exclusives from the monopolist even if the entrant offers a premium. $\underline{\text { Id. at } 395 .}$ 
stakes than do private plaintiffs. This asymmetry distorts litigation incentives and likely leads to a higher incidence of false negative errors. In an exclusionary conduct matter, for example, the defendant is attempting to maintain or increase its ability to exercise market power. Its litigation stakes from an injunction are equal to the reduction in profits from its resulting loss in market power. An entrant attempting to weaken that market power by enjoining the conduct so that it can compete in the more competitive market has stakes equal to its competitive profits. These stakes are highly asymmetric because competitive profits typically are much lower than monopoly profits. They also are asymmetric because the benefits of the injunction often would be shared with other competitors. Damages (even if trebled) are a one-to-one transfer payment, which raise the stakes equally to both parties but do not eliminate the asymmetric stakes from the injunction. ${ }^{97}$

Because a defendant with substantial market power has higher stakes in an exclusionary conduct case, it has systematic incentives to invest in higher litigation effort than the plaintiff in order to tilt the outcome somewhat in its favor, relative to the underlying merits of the case. These asymmetric litigation investment incentives lead the defendant to provide more evidence to the court than does the plaintiff, and the court to treat this additional evidence as weakening the plaintiff's case, so that the court is less likely to find for the plaintiff relative to the underlying merits of the plaintiff's case. As a result, judicial outcomes will involve relatively more false negatives and relatively fewer false positives, which also will lead to underdeterrence. ${ }^{98}$ Many rules of procedure and evidence, despite judicial oversight, also provide

${ }^{97}$ Treble damages do increase the incentive to bring cases, which can increase deterrence. But they are unlikely to offset the other deterrence-reducing effects.

${ }^{98}$ For further analysis, see Erik Hovenkamp \& Steven C. Salop, Asymmetric Stakes in Antitrust Litigation, (Mar. 29, 2020) (unpublished manuscript) (on file with author), 
ample opportunities for strategic use of litigation to delay, raise plaintiffs' litigation costs, and further tilt outcomes. ${ }^{99}$ Moreover, by the time a case is decided, a rival may have exited the market or been so hobbled that it no longer poses a significant competitive threat, which renders injunctive relief ineffective. These factors collectively reduce the plaintiff's incentive to bring suit, which leads to further under-deterrence.

It has long been recognized that the pursuit of monopoly spurs innovation. ${ }^{100}$ However, this argument is sometimes misinterpreted to suggest that monopoly, once achieved, benefits

https://papers.ssrn.com/sol3/papers.cfm?abstract_id=3563843_[https://perma.cc/37XDWMND]. See also Avery Katz. Judicial Decisionmaking and Litigation Expenditure, 8 Int'l Rev. of L. \& Econ. 127 (1988); Svetoslav Salkin, Rent Seeking with Asymmetric Players: An Application to Litigation Expenditures, 6 Eur. J. of Legal Stud. 157 (2013). An analogous analysis explains how asymmetric stakes in patent races favor the incumbent monopolist. Richard J. Gilbert and David M.G. Newbery, Preemptive Patenting and the Persistence of Monopoly. 72 Am. Econ. Rev. 514 (1982).

${ }^{99}$ These can include motions to dismiss and challenges to standing and antitrust injury, aggressive opposition to various aspects of discovery and to class certification, efforts to exclude necessary expert testimony, motions for summary judgment, and post-trial motions.

${ }^{100}$ See, e.g., Joseph A. Schumpeter, Capitalism, Socialism, Democracy 110 (1942):

Was not the observed performance due to that stream of inventions that revolutionized the technique of production rather than to the businessman's hunt for profits? The answer is in the negative. The carrying into effect of those technological novelties was of the essence of that hunt. And even the inventing itself . . . was a function of the capitalist process which is responsible for the mental habits that will produce invention. It is therefore quite wrong . . . to say, as so many economists do, that capitalist enterprise was one, and technological progress a second, distinct factor in the observed development of output; they were essentially one and the same thing or, as we may also put it, the former was the propelling force of the latter.

See also Giulio Federico, Fiona Scott Morton \& Carl Shapiro, Antitrust and Innovation: Welcoming and Protecting Disruption, in Innovation Policy and the Economy 20 125, 126 (Josh Lerner \& Scott Stern eds. 2020) ("The goal of antitrust policy is to protect and promote a vigorous competitive process. Effective rivalry spurs firms to introduce new and innovative products, as they seek to capture profitable sales from their competitors 
consumers because the monopolist's future innovation incentives exceed the incentives of their would-be rivals. ${ }^{101}$ In fact, monopolists and dominant firms have less incentive to innovate because they already have a monopoly market share, whereas fringe competitors have the potential to grow their shares. What mainly incentivizes a dominant firm is the fear of losing out to new competitors. ${ }^{102}$ Moreover, that fear can also incentivize the monopolist to engage in exclusionary conduct to erect barriers against these potential innovators. This incentive can be further amplified if the plaintiff's standard of proof has been raised based on mistaken assumptions. The combination of a desire to preserve monopoly profits, awareness that the potential plaintiff's burden of proof will be demanding, and the possibility that innovating rivals may not be able to foot the cost of protracted litigation and survive in the marketplace all combine to insulate monopolists from challenge. ${ }^{103}$

There are exceptions to the judicial success of these non-interventionist assumptions about exclusionary conduct. In Actavis, the Court recognized that an innovator that legitimately

and to protect their existing sales from future challengers. In this fundamental way, competition promotes innovation."), https://www.nber.org/books/lern-13.

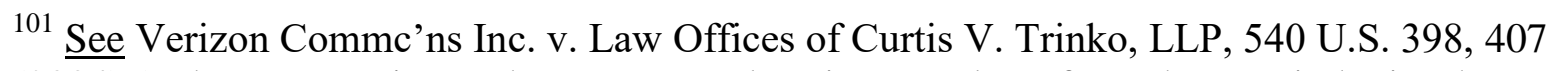
(2004) ("The opportunity to charge monopoly prices—at least for a short period—is what attracts 'business acumen' in the first place; it induces risk taking that produces innovation and economic growth."). This view arguably signaled a departure from the attitude about monopoly power reflected in United States v. Alum. Co. of Am., 148 F.2d 416, 427 (2d Cir. 1945) ("Many people believe that possession of unchallenged economic power deadens initiative, discourages thrift and depresses energy; that immunity from competition is a narcotic, and rivalry is a stimulant, to industrial progress; that the spur of constant stress is necessary to counteract an inevitable disposition to let well enough alone.").

${ }^{102}$ Carl Shapiro, Competition and Innovation: Did Arrow Hit the Bull's Eye?, (reviewing evidence) in The Rate and Direction of Inventive Activity Revisited 361, 376-92 (Josh Lerner $\&$ Scott Stern eds., 2012).

${ }^{103}$ For a more comprehensive discussion of the debate over innovation incentives, see Jonathan B. Baker, Beyond Schumpeter vs. Arrow: How Antitrust Fosters Innovation, 74 Antitrust L.J. 575 (2007); see also infra note 123. 
has obtained a patent monopoly should not be permitted to strike agreements with potential entrants that would exclude them from the market for some period of time. ${ }^{104}$ In Leegin, the Court recognized exclusionary conduct concerns from resale price maintenance--it explained how vertical restraints can be used to maintain single firm market power by foreclosing innovative retailers or manufacturers. ${ }^{105}$ Similarly, several circuit courts have recognized the significant anticompetitive concerns from exclusive dealing and similar conduct by firms with substantial market power, especially when implemented in response to new competitive challenges. $^{106}$

In Microsoft, the D.C. Circuit explained how exclusionary conduct can erect anticompetitive entry barriers to innovative, nascent competitors, ${ }^{107}$ and endorsed a structured, burden-shifting framework for evaluating exclusionary conduct akin to the Section 1 rule of reason standard that requires defendants to establish procompetitive justifications for their

${ }^{104}$ FTC v. Actavis, Inc., 570 U.S. 136, 158 (2013).

${ }^{105}$ Leegin Creative Leather Prods., Inc. v. PSKS, Inc., 551 U.S. 877, 893 (2007) (“A dominant retailer, for example, might request resale price maintenance to forestall innovation in distribution that decreases costs."). See also John Asker \& Heski Bar-Isaac, Raising Retailers' Profits: On Vertical Practices and the Exclusion of Rivals, 104 Am. Econ. Rev. 672 (2014) (examining exclusionary uses of minimum resale price maintenance and other vertical contracting practices).

${ }^{106}$ See, e.g., McWane, Inc. v. FTC, 783 F.3d 814, 827 (11th Cir. 2015) (“[Exclusive dealing] arrangements can harm competition in certain circumstances ....”); see also ZF Meritor, LLC v. Eaton Corp., 696 F.3d 254, 270 (3d Cir. 2012) ("The primary antitrust concern with exclusive dealing arrangements is that they may be used by a monopolist to strengthen its position, which may ultimately harm competition."); United States v. Dentsply Int'l, Inc., 399 F.3d 181, 196 (3d Cir. 2005) ("The economic impact of an exclusive dealing arrangement is amplified in the stagnant, no growth context of the artificial tooth field."); Conwood Co. v. U.S. Tobacco Co., 290 F.3d 768, 783 (6th Cir. 2002) ("[Plaintiff] presented sufficient evidence that USTC sought to achieve its goals of excluding competition and competitors' products by .... [E]nter[ing] into exclusive agreements with retailers in an effort to exclude rivals' products.").

${ }^{107}$ United States v. Microsoft Corp., 253 F.3d 34, 79 (D.C. Cir. 2001). 
conduct once the plaintiff has met its initial burden of showing anticompetitive effects. ${ }^{108}$ In $\underline{\mathrm{ZF}}$

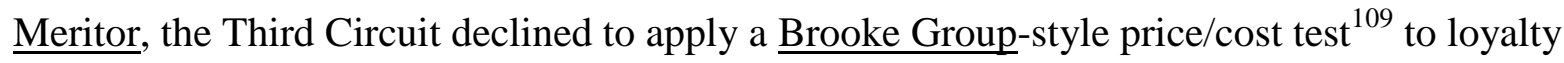
discounts accompanied by other exclusionary contract restrictions, relying instead on a similar, burden-shifting structure. ${ }^{110}$ In McWane, the Eleventh Circuit also applied a Section 1 rule of reason approach to exclusive dealing and declined to adopt a procompetitive presumption. ${ }^{111}$ The

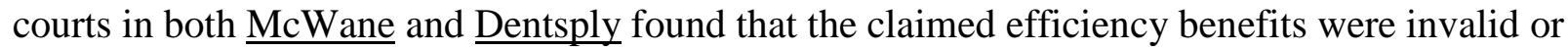
non-existent, as did the Microsoft court for most of the challenged restraints. ${ }^{112}$

Despite this progress, the skeptical assumptions of some conservatives continue to run deep in antitrust analysis and law. Plaintiffs continue to face arguments about conduct, institutions, and market structure to persuade courts to impose overly demanding burdens of production and proof. Most recently, in Ohio v. American Express Co., the Court declined to rely on direct evidence of anticompetitive effect of the challenged exclusionary vertical restraints in the context of a two-sided platform. ${ }^{113}$ It instead mandated that proof of market power through circumstantial evidence in the form of a defined relevant market was also required despite the

108 Id. at 58-59.

${ }^{109}$ Brooke Group established a two-part the test for predatory pricing that requires evidence of both below cost pricing and a probability that the alleged predator will be able to later recoup its losses. Brooke Grp. Ltd. v. Brown \& Williamson Tobacco Corp., 509 U.S. 209, 222-24 (1993).

${ }^{110}$ ZF Meritor, 696 F.3d at 277 ("[B]ecause price itself was not the clearly predominant mechanism of exclusion, the price-cost test cases are inapposite, and the rule of reason is the proper framework within which to evaluate Plaintiffs' claims.").

${ }^{111}$ McWane, 783 F.3d at 833-35.

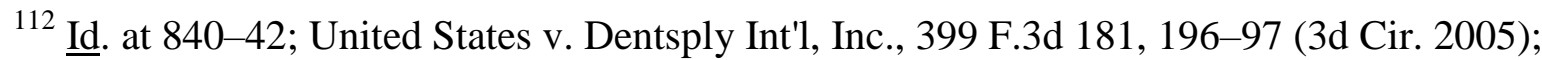
Microsoft, 253 F.3d at 62-64; 66-67; 71-72.

113 Ohio v. Am. Express Co., 138 S. Ct. 2274, 2285 n.7 (2018). 
fact that the direct evidence of anticompetitive effects on consumers also proved that the defendant had market power. ${ }^{114}$

In light of this history, the time has come to consider more systematically how a more modern analysis should be combined with the insights of decision theory to update antitrust presumptions and the burden of proof placed on plaintiffs under the rule of reason in exclusionary conduct challenges. In this way, the sliding-scale "enquiry meet for the case" can be formulated for the current market environment. Analysis based on mistaken assumptions and mistaken applications of decision theory are particularly worrisome in light of the growing role of "new economy" markets that involve network effects and economies of scale that often naturally tip these markets to dominance or monopoly and lead to durable barriers to entry. ${ }^{115}$ These barriers can be maintained or enhanced in the face of innovative potential entrants by technological as well as traditional exclusionary conduct such as exclusive dealing, tying, and

${ }^{114} \underline{I d}$. As Justice Breyer points out in dissent, the Court's previous recognition that direct evidence of competitive harm is sufficient to shift a burden of production to the defendant and require a showing of procompetitive effects should have been "fully applicable" in the case. Id. at 2296 (Breyer, J., dissenting). Breyer further observed that " $[\mathrm{t}]$ he majority thus, in a footnote, seems categorically to exempt vertical restraints from the ordinary 'rule of reason' analysis that has applied to them since the Sherman Act's enactment in 1890" and adds that "[o]ne critical point that the majority's argument ignores is that proof of actual adverse effects on competition is, a fortiori, proof of market power. Without such power, the restraints could not have brought about the anticompetitive effects that the plaintiff proved." Id. at 2297.

${ }^{115}$ In the Second Edition of his antitrust law treatise, Judge Posner recognized the greater concerns about exclusionary conduct in "new economy" markets such as internet platforms with network effects. However, he still proposed that the monopolist is entitled to use practices that are employed widely in industries that resemble the monopolist's but are competitive. Richard A. Posner, Antitrust Law 253-54 (2d ed. 2001). 
vertical mergers, and various kinds of contractual restraints, as well as by serial acquisition strategies that eliminate the most promising potential competitors. ${ }^{116}$

\section{Recommended Guiding Principles for Operationalizing the "Enquiry Meet for the Case" For Anticompetitive Exclusionary Conduct}

$\underline{\text { California Dental Ass'n }},{ }^{117} \underline{\text { Leegin }}^{118}$ and $\underline{\text { Actavis }}^{119}$ invited courts to continue to formulate evidentiary burdens, including presumptions, as they gain more experience under the rule of reason. In response to that invitation, we propose a set of "guiding principles" for courts evaluating the competitive effects of exclusionary conduct. These proposals reflect decision theory, modern economic analysis and legal precedent, and current market conditions. They are intended to structure the inquiry in a rational way, correcting for the various mistaken assumptions that exaggerate current perceptions of the likelihood of false positives, understate concerns for false negatives, and impose excessive burdens on plaintiffs.

In the conventional rule of reason decision framework, the plaintiff bears the initial burden of producing sufficient evidence of likely competitive harm. It can satisfy this burden with direct or circumstantial evidence, an appropriate anticompetitive presumption, or some combination. If the plaintiff satisfies this requirement, the burden of production shifts to the defendant to provide justifications, that is, sufficient evidence of cognizable procompetitive

\footnotetext{
${ }^{116}$ Indeed, while no single acquisition may be likely to "substantially lessen competition" and so violate Section 7, the series might be susceptible to analysis as monopolizing conduct under Section 2.

${ }^{117}$ Cal. Dental Ass'n v. FTC, 526 U.S. 756, 779-80 (1999).

${ }^{118}$ Leegin Creative Leather Prods., Inc. v. PSKS, Inc., 551 U.S. 877, 898-99 (2007) ("Courts can, for example, devise rules over time for offering proof, or even presumptions where justified, to make the rule of reason a fair and efficient way to prohibit anticompetitive restraints and to promote procompetitive ones.").

${ }^{119}$ FTC v. Actavis, Inc., 570 U.S. 136, 158-60 (2013).
} 
benefits of the challenged conduct. ${ }^{120}$ If the defendant satisfies this requirement, the burden of production then shifts back to the plaintiff, who bears the ultimate burden of persuasion by a preponderance of the evidence, i.e., that the conduct is more likely to be anticompetitive than not.

This is a sliding scale standard in that stronger evidence of competitive harm (or a stronger anticompetitive presumption) requires the defendant to produce stronger evidence of efficiency benefits, and vice versa. A procompetitive presumption analogously would require the plaintiff to provide stronger evidence of competitive harm. The inevitable uncertainty that accompanies antitrust decision-making requires reasonable means of assessing and determining the probability of competitive harm in the first step, including the relevant presumptions.

We propose a number of principles to guide the implementation of this framework, including the allocation of burdens and the adoption of anticompetitive and procompetitive presumptions.

\section{A. Basic Structure of the Inquiry and Allocation of Burdens}

1. The Default Presumption Under the Rule of Reason Should Be "Neutral" Competitive Effects

\footnotetext{
${ }^{120}$ A presumption may be rebutted by evidence undermining its basis or "affirmatively" offsetting its implication. United States v. Baker Hughes Inc., 908 F.2d 981, 991 (D.C. Cir. 1990). As one court recently held, however, the burden of pleading should be distinguished from the burden of production. See Viamedia, Inc. v. Comcast Corp., 951 F.3d 429, 460 (7th Cir. 2020) ("[B]alancing anticompetitive effects against hypothesized justifications depends on evidence and is not amenable to resolution on the pleadings . ..."); see also $\underline{\mathrm{id} .}$ at 462 ("[T]he calculation of procompetitive benefits net of anticompetitive harms does not easily lend itself to a pleading standard.").
} 
Civil antitrust claims generally do not warrant different treatment than any other kind of civil enforcement. The rule of reason benchmark standard requires the plaintiff to prove that anticompetitive effects are "more likely than not," or, as it applies to all civil antitrust cases, "by a preponderance of the evidence." This evidentiary standard is consistent with a "neutral" presumption of likely competitive effects, that is, that the category of conduct is no more likely to reduce consumer welfare than to increase welfare. ${ }^{121}$

For example, Leegin adopted the conventional rule of reason, which requires the plaintiff to show likely anticompetitive effects by a preponderance of the evidence. While it eliminated the previous anticompetitive presumption, it also detailed circumstances under which minimum resale price maintenance could be anticompetitive, and adopted a neutral ex ante presumption, not a procompetitive presumption.

The next several principles explain the appropriate evidentiary burden on the plaintiff.

\section{The Plaintiff's Evidentiary Burden Should Not Be Elevated Ex Ante}

a. The Plaintiff's Evidentiary Burden Should Be Probable Anticompetitive Effects, Not Actual

\section{$\underline{\text { Anticompetitive Effects }}$}

As discussed in Part I, the rule of reason has always focused on probable anticompetitive effects and "tendency." It should be sufficient for the plaintiff to satisfy its initial burden and shift the burden to the defendant by showing either actual or probable anticompetitive harm, not definitive proof.

b. The Plaintiff's Evidentiary Burden Should Not Require Quantification

${ }^{121}$ The fact that ties are resolved in favor of the defendant might suggest that the presumption is "marginally procompetitive" rather than "neutral." If so, the "margin" is considered very small. But see generally Mungan \& Wright, supra note 71 (advocating a higher than preponderance standard for antitrust). 
Courts should not require quantification of harm as part of the plaintiff's burden. Quantification evidence of "actual" harm is not required by the leading cases, which simply recognize that direct evidence of likely harm obviates the need for circumstantial proof. ${ }^{122}$ Moreover, imposing a requirement of evidence of actual harm would move the needle from reasonable probability closer to a standard of near-certainty more typically associated with criminal prosecution, and likely would lead to excessive false negatives.

A quantification requirement would also add substantial and unnecessary additional cost resulting from discovery and protracted litigation over expert methodologies. No empirical methodology is perfect, and complete and accurate information is likely to be rare, so some criticisms can be made of even the most rigorous and careful empirical methodology. Evaluating the importance of the criticisms can be difficult for generalist courts facing significant docket pressures. This distortion is exacerbated by the fact that the standard test for statistical significance of econometric results is focused on avoiding false positives and places no value on avoiding false negatives. ${ }^{123}$

3. Direct Proof of Market Power or Anticompetitive Effects Should Obviate the Need for Circumstantial Proof

When reliable direct evidence of market power or anticompetitive effect is presented, courts should not require plaintiffs to also demonstrate market power with circumstantial evidence by defining a relevant market, calculating market shares, and evaluating barriers to

${ }^{122}$ Cal. Dental Ass'n v. FTC, 526 U.S. 756, 769-70 (1999); FTC v. Ind. Fed'n of Dentists, 476 U.S. 447, 460-61 (1986); Nat'l Collegiate Athletic Ass'n v. Bd. of Regents of the Univ. of Okla., 468 U.S. 85, 103 (1984); Nat'l Soc'y of Prof'l Eng'rs v. United States, 435 U.S. 679, 690 (1978).

${ }^{123}$ Cf. Phillip Johnson, Edward Leamer \& Jeffrey Leitzinger, Statistical Significance and Statistical Error in Antitrust Analysis, 81 Antitrust L.J. 641, 643 (2017) (arguing for an approach that recognizes false negatives). 
entry. As the Court observed in Indiana Federation of Dentists, market power inferred from market shares in a defined market is a second best "surrogate" and is unnecessary when more direct evidence of market power or anticompetitive effects is provided.

In evaluating exclusionary conduct, courts also should avoid the false negatives that would result from failing to connect the market power analysis to the allegations of anticompetitive effect. In a monopoly maintenance case, for example, a court should not evaluate the profitability of price increases since the allegation centers on conduct designed to prevent price decreases. ${ }^{124}$ Courts also should not immunize exclusionary conduct by monopolists by using a threshold market power filter to conclude that a firm lacks monopoly power because it faces competition when it is accused of using that power to impair or destroy those very competitors.

In American Express, the Court required the plaintiff to prove market power in the twosided platform with circumstantial evidence, despite the fact that direct evidence of anticompetitive effects was provided and should have been sufficient economic proof of market power. ${ }^{125}$ Imposing that additional requirement is inefficient and merely raises the plaintiff's cost, while potentially masking the defendant's lack of sufficient justification because it prevents the burden from shifting. It makes no economic or legal sense to require inferior evidence when superior evidence already has been provided. If the Court wished to raise the plaintiff's evidentiary burden, it would have been better to require additional evidence of harm, as discussed below. ${ }^{126}$

\footnotetext{
${ }^{124}$ See Salop, supra note 30, at 194-201 (discussing "Cellophane Trap" and variants in a first principles approach).

${ }^{125}$ Ohio v. Am. Express Co., 138 S. Ct. 2274, 2288 (2018).

${ }^{126}$ See supra note 114 (discussing Justice Breyer's criticisms of the majority's approach).
} 
4. Courts Should Set a Lower Burden on the Plaintiff in Exclusionary Conduct Cases When the Defendant Has Substantial Market Power

Anticompetitive effects are more likely when the defendant has substantial market power. Moreover, when the defendant has substantial market power, the asymmetric litigation incentive effects from its higher stakes can lead to false negatives. Both of these factors suggest that courts should resist imposing elevated burdens on plaintiffs in such circumstances and should instead impose a lower burden to reflect the greater probability of competitive harm and the distinct challenges of litigation against a dominant firm. This is consistent with the sliding scale and the view that behavior by monopolists should be viewed through a "special lens," precisely because its power may provide it with the ability and incentive to engage in exclusionary conduct. ${ }^{127} \mathrm{We}$ are not, however, suggesting that substantial market power without additional evidence warrants a presumption of competitive harm.

As we have explained, many of the arguments that firms possessing market power lack incentives to carry out exclusionary conduct have been debunked. Market self-correction requires existing competitors or new entrants that can expand in response to attempts to raise or maintain monopoly prices. But monopoly power includes entry barriers, and exclusionary

${ }^{127}$ See Eastman Kodak Co. v. Image Tech. Servs., Inc., 504 U.S. 451, 488 (1992) (Scalia, J., dissenting) ("Where a defendant maintains substantial market power, his activities are examined through a special lens: Behavior that might otherwise not be of concern to the antitrust laws--or that might even be viewed as procompetitive--can take on exclusionary connotations when practiced by a monopolist."); United States v. Dentsply Int'l, Inc. 399 F.3d 181, 187 (3d Cir. 2005) ("Behavior that otherwise might comply with antitrust law may be impermissibly exclusionary when practiced by a monopolist."). 
conduct often raises barriers to entry. If there are no competitors who are not subject to the exclusionary conduct, this self-correction process cannot occur. ${ }^{128}$

The plaintiff's evidentiary burden also should be reduced to reflect the asymmetric litigation stakes and the associated increased likelihood of false negatives. As discussed earlier, these asymmetric stakes give defendants with substantial market power systematic incentives to invest in relatively greater litigation efforts. These asymmetric litigation incentives tilt outcomes in the direction of excessive false negatives.

Despite the substantial harms caused by monopolizing conduct, the plaintiff's burden in Section 2 monopolization cases often was treated as higher. One reason was grounded in remedial concerns. The traditional remedy for monopolization was "capital punishment," the disintegration of the firm into separate parts, as in Standard Oil, ${ }^{129}$ United Shoe Machinery, ${ }^{130}$ or the United States v. AT\&T settlement. ${ }^{131}$ But it is now recognized that remedial concerns in Section 2 cases can be separated from liability standards because other equitable remedies, such as divestitures short of complete dissolution or behavioral remedies, may be mandated instead. ${ }^{132}$ A second reason may have been the categorical assumption made explicit by the Court in

${ }^{128}$ As discussed earlier, counterstrategies by plaintiffs to outbid the monopolist to escape exclusives are unlikely to succeed because of the monopolist's greater stakes. See supra text accompanying note 97.

${ }^{129}$ Standard Oil Co. of N.J. v. United States, 221 U.S. 1, 77-82 (1911) (ordering the dissolution of Standard Oil).

${ }^{130}$ United States v. United Shoe Mach. Corp., 391 U.S. 244, 250-52 (1968) (discussing conditions under which divestiture can be an appropriate remedy in a monopolization case).

${ }^{131}$ United States v. AT\&T Co., 552 F. Supp. 131, 160-70 (D.D.C. 1982) (determining that the proposed divestiture from AT\& $\mathrm{T}$ is in the public interest).

${ }^{132}$ See, e.g., United States v. Microsoft Corp., 253 F.3d 34, 105-07 (D.C. Cir. 2001) (remanding for consideration of whether divestiture is an appropriate remedy); see also Andrew I. Gavil \& Harry First, The Microsoft Antitrust Cases 237-38 (2014) (discussing theoretical framework for remedies in monopolization cases). 
Copperweld that unilateral exclusionary conduct is less of a threat to competition than is concerted action under Section $1 .{ }^{133}$ But concerted action by smaller rivals in highly competitive markets is unlikely to threaten competition to the same extent as unilateral exclusionary conduct by a firm possessing substantial market power.

5. The Plaintiff's Initial Evidentiary Burden Should Be Reduced to Reflect the Possible Absence of a Valid Efficiency Justification

The conventional statement of the burden-shifting rule of reason typically suggests that the defendant's justifications must be totally ignored unless, and until, the plaintiff produces sufficient evidence of competitive harm, where that evidence does not include any reference to the possible lack of cognizable justifications. Such a rigid sequencing approach can lead to excessive false negatives. ${ }^{134}$

Evaluating competitive harm first and in isolation in exclusionary conduct cases involving dominant firms is not compelled or even suggested by decision theory ${ }^{135}$ and doing so

${ }^{133}$ Copperweld Corp. v. Indep. Tube Corp., 467 U.S. 752, 768-69 (1984).

${ }^{134}$ In his dissent in McWane, Commissioner Wright demanded a high evidentiary burden (i.e., "clear evidence") on the plaintiff to establish competitive harm in the first step to take account of his view that the defendant's conduct was presumptively procompetitive. He concluded that the plaintiff failed this first step, so he never analyzed the validity of the defendant's procompetitive claims. In fact, they were found by the Commission (and the Eleventh Circuit) to be pretextual and invalid. But Commissioner Wright never analyzed them or contemplated the possibility that they might be pretextual, thereby seeking to impose an overly high bar on the plaintiff's proof of harm in the first step. McWane, Inc., Docket No. 9351, 50-52 (F.T.C. Feb. 6, 2014) (Dissenting Statement of Commissioner Joshua D. Wright), https://www.ftc.gov/publicstatements/2014/02/dissenting-statement-commissioner-joshua-d-wright-matter-mcwane-inc [https://perma.cc/76JD-DSF7].

${ }^{135}$ See Beckner \& Salop, supra note 61, at 69 ("Thus, in decision theoretic terms, the benefit of gathering information on efficiencies exceeds the benefit of gathering information about market power harms. On the cost side, the view seems to be that it is relatively more difficult to gather information on implicit market power harms than on efficiency benefits."). 
is inconsistent with a sliding scale approach to the burden of proof, which evaluates all of the evidence. ${ }^{136}$ Moreover, the courts have long acknowledged that evidence of the defendant's purpose in adopting certain restraints can be probative for evaluating the likelihood of competitive effects. ${ }^{137}$ The absence of a cognizable justification, for example, can strengthen a presumption of harm. ${ }^{138}$

If consideration of the justifications is deferred, then the plaintiff's burden to show competitive harm should be set at a low level to account for the fact that any efficiency claims may turn out to be pretextual, invalid, or very small. This approach would allow the sequential burden-shifting structure to be maintained without causing excessive false negatives. ${ }^{139}$

6. The Defendant Should Not Be Able to Meet Its Burden of Production to Show Cognizable Efficiency Benefits Based on Purely Categorical Justifications

${ }^{136}$ Sequential analysis fits better in the context of motion practice, such as summary judgment and judgment as a matter of law, both of which specifically test the non-movant's ability to meet its burden of production.

${ }^{137}$ See, e.g., Bd. of Trade of Chi. v. United States, 246 U.S. 231, 238 (1918) ("[K]nowledge of intent may help the court to interpret facts and to predict consequences."). Applied to monopolization under Section 2, the Court in Aspen Skiing inferred anticompetitive purpose from the defendant's lack of a valid efficiency benefit. Aspen Skiing Co. v. Aspen Highlands Skiing Corp., 472 U.S. 585, 608 n.39 (1985) ("[I]ntent to engage in predation may be in the form of . . evidence that the conduct was not related to any apparent efficiency." (quoting Robert $\mathrm{H}$. Bork, The Antitrust Paradox 157 (1978))); see also United States v. Microsoft Corp., 253 F.3d 34, 59 (D.C. Cir. 2001) ("Evidence of the intent behind the conduct of a monopolist is relevant ... to the extent it helps us understand the likely effect of the monopolist's conduct."). In McWane, the court discussed the evidence of McWane's anticompetitive purpose in its discussion of the plaintiff's evidence of competitive harm. McWane, Inc. v. FTC, 783 F.3d 814, 840 (11th Cir. 2015).

${ }^{138}$ See, e.g, Nat'1 Soc'y of Prof'l Eng'rs v. United States, 435 U.S. 679, 693 (1978) (“The Society's affirmative defense confirms rather than refutes the anticompetitive purpose and effect of its agreement.").

${ }^{139}$ See, e.g., Louis Kaplow, On the Design of Legal Rules: Balancing Versus Structured Decision Procedures, 132 Harv. L. Rev. 992, 997-1003 (2019). 
Categorical justifications are often urged by defendants and conservative commentators to support procompetitive presumptions. But general categorical evidence of benefits, especially when based on evidence from competitive markets as is often the case, should not be sufficient to carry the defendant's burden once the plaintiff produces evidence of probable competitive harm. Case-specific evidence then must be produced to support efficiency claims to support the application of the theory to the particular case. Permitting purely theoretical justifications to satisfy the defendant's burden in a particular case would amount to a sub rosa presumption and would lead to excessive false negatives. Justifications must be evaluated solely with the casespecific evidence when there is no procompetitive presumption. For example, the fact that some exclusive dealing arrangements may be procompetitive does not mean that the one at issue is procompetitive.

This is consistent with the treatment of theoretical evidence of competitive harm. A plaintiff may be able to defeat a motion to dismiss if it explains its theory of harm and if its claim is supported by allegations sufficient to make the claim plausible. But case-specific evidence is required to avoid summary judgement. The same approach should be followed with respect to theoretical evidence of efficiency benefits.

7. Courts Should Subject Defendant's Justifications to a Less Restrictive Alternative Standard

Courts should consider whether the claimed procompetitive benefits can be achieved in large part through less restrictive alternatives that involve significantly lessened competitive concerns. For example, once a defendant has shifted the burden back to the plaintiff by showing a procompetitive justification, the plaintiff should be able to shift the burden back to the defendant by identifying a plausible less restrictive alternative. At that 
point the burden would shift back to the defendant to demonstrate why that alternative is not feasible or would not achieve most or substantially all of the efficiency benefits. This allocation of burdens makes sense since the defendant has superior information regarding efficiencies. ${ }^{140}$

B. Guiding Principles for Adopting Procompetitive Presumptions for Exclusionary Conduct by Firms with Substantial Market Power

1. Substantial Evidence Should Be Required to Justify Procompetitive Presumptions In light of the heightened concern about the anticompetitive effects of exclusionary conduct by firms with substantial market power, adoption of procompetitive presumptions for such conduct should be rare and endorsed only under exceptional circumstances. Compared to the state of antitrust law in the 1960s, defendants today have far more effective and robust procedural options at hand to identify and eliminate truly weak antitrust claims through motions to dismiss, motions for summary judgment, and motions to exclude expert testimony. Procompetitive presumptions, therefore, should be narrowly tailored and justified by substantial theoretical or empirical categorical evidence.

\section{a. Narrow Categories}

Presumptions involving categories of conduct should be narrowly drawn and courts should be cautious about generalizing either from one type of conduct to another or from conduct

${ }^{140}$ See C. Scott Hemphill, Less Restrictive Alternatives in Antitrust Law, 116 Colum. L. Rev. 927, 982 (2016) (arguing that although plaintiffs bear the burden of persuasion, defendants should bear a burden of production because, among other reasons, they "have better access to information about their reasons for adopting a particular practice"). See generally Kaplow, supra note 139, at 1003-15 (discussing how less restrictive alternatives analysis fits in with structured decision procedures). 
in competitive settings to that in highly concentrated markets. The fact that a class of conduct sometimes creates plausible procompetitive benefits may be a reason to reject an irrebuttable anticompetitive presumption, but it does not justify a procompetitive presumption. Moreover, the fact that certain conduct is carried out by firms lacking market power in competitive markets does not mean that such conduct would be procompetitive in an oligopoly market or when implemented by a firm with substantial market power. Even if the conduct has some procompetitive benefits, it may be anticompetitive in a particular case because the market context is different. ${ }^{141}$ Thus, while that evidence may be probative in a particular case, where the conditions are sufficiently similar, it cannot justify a procompetitive presumption.

For example, while conceding that vertical intrabrand restraints can have procompetitive virtues and therefore did not warrant per se condemnation, neither Leegin nor Sylvania endorsed a presumption that they were more likely procompetitive than anticompetitive. Instead, both restored a neutral competitive presumption. ${ }^{142}$ Similarly, the fact that certain intrabrand vertical restraints may be useful in achieving procompetitive efficiencies does not mean that a procompetitive presumption should be applied to interbrand vertical restraints. Neither Leegin nor Sylvania made judgments about interbrand vertical restraints with possible exclusionary effects, such as exclusive dealing or most-favored nation ("MFN") provisions. ${ }^{143}$

\footnotetext{
${ }^{141}$ It also may be the case that smaller firms are simply imitating the behavior of the dominant firm.

${ }^{142}$ Studies of the mixed impact of resale price maintenance on welfare during periods when it was legal were discussed in Leegin. Leegin Creative Leather Prods., Inc. v. PSKS, Inc., 551 U.S. 877, 893, 895, 900 (2007).

${ }^{143}$ See, e.g., United States v. Dentsply Int'1, Inc., 399 F.3d 181, 187 (3d Cir. 2005) (“Although not illegal in themselves, exclusive dealing arrangements can be an improper means of maintaining a monopoly.").
} 
Similarly, just as the fact that certain conduct is "horizontal" does not automatically justify an anticompetitive presumption, "vertical" conduct should not lead automatically to a procompetitive presumption. Labelling the conduct as "horizontal" or "vertical," without more, provides insufficient information to formulate any generally applicable presumption. While conduct might be vertical in form, any anticompetitive effects are horizontal. ${ }^{144}$

\section{b. False Positives and False Negatives}

Chicago-School claims about false negatives were formulated at a time when courts were relying on relatively low burdens of proof and arguably expansive anticompetitive presumptions, including a number of per se prohibitions. Those concerns are now anachronistic and largely overstated given the evolution of the conventional rule of reason. The enforcement agencies and the courts also have become more knowledgeable and experienced in evaluating economic evidence. For this reason, it makes sense today to assume that the error costs from false positives and false negatives are relatively equal. Substantial evidence about the particular category of conduct should be required, therefore, to justify placing greater weight on false positives.

It will seldom be possible to gauge the impact of alternative legal rules (aside from per se rules) on deterrence. If the legal standard is stable, it is hard to quantify the relative number and competitive impact of additional false negatives versus fewer false positives if the law were made more permissive. ${ }^{145}$ However, deterrence policy concerns could alter the presumption in highly exceptional circumstances. For example, Brooke Group created a procompetitive

\footnotetext{
${ }^{144}$ Bus. Elecs. Corp. v. Sharp Elecs. Corp., 485 U.S. 717, 728-30 (1988).

${ }^{145}$ See generally Alexander MacKay \& David Aron Smith, The Empirical Effects of Minimum Resale Price Maintenance (Chi. Booth Kilts Ctr. for Mktg,, Paper No. 2-006, 2014), http://alexandermackay.org/files/The\%20Empirical\%20Effects\%20of\%20MRPM.pdf [https://perma.cc/8AGC-5CF9].
} 
presumption for price cuts in response to competition that remain above costs based on the view that such price cuts are a natural competitive response, immediately benefit consumers, and any line drawing by courts would lead to a severe risk of deterring beneficial price cuts. ${ }^{146}$

2. When an Appropriate Procompetitive Presumption Is Adopted, It Should Raise the Plaintiff's Burden to Show Competitive Harm, Not Append Additional Evidentiary

Requirements

If it is appropriate to place a higher burden of proof on the plaintiff, the rule of reason can accommodate that standard by requiring the plaintiff to prove that the conduct "produce harms disproportionate to the resulting benefits," as suggested by Professor Hovenkamp. ${ }^{147}$ By contrast, in setting a higher burden on the plaintiff (apparently because the conduct was labelled "vertical"), the Court in American Express required the plaintiff to prove market power by circumstantial evidence despite the fact that better, direct evidence of anticompetitive effects was already provided. ${ }^{148}$ Even if it were justified, it would have made more sense for the Court to require a stronger showing of anticompetitive effects, rather than adding unnecessary evidence of market power simply as a make-weight. ${ }^{149}$

As another example, it has been suggested that the plaintiff should be required to provide evidence that that the defendant's conduct would make "no economic sense" in the absence of

\footnotetext{
${ }^{146}$ Brooke Grp. Ltd. v. Brown \& Williamson Tobacco Corp., 509 U.S. 209, 222-26 (1993).

${ }^{147}$ Herbert Hovenkamp, Exclusion and the Sherman Act, 72 U. Chi. L. Rev. 147, 148 (2005) (citing Phillip E. Areeda and Herbert Hovenkamp, 3 Antitrust Law: An Analysis of Antitrust Principles and Their Application II 651a, at 72 (Aspen 2d ed. 2002)).

148 Ohio v. Am. Express Co., 138 S. Ct. 2274, 2285 n.7 (2018).

${ }^{149}$ Brooke Group again is an exception to this principle in that it added the below-cost pricing prong to its standard for evaluation of competitive price cuts. 509 U.S. at 223.
} 
gaining monopoly power in addition to evidence of anticompetitive effects. ${ }^{150}$ This approach would redirect the rule of reason inquiry away from its proper, sole focus on competitive effects. Instead of merely showing that the challenged conduct was anticompetitive, plaintiffs would also have to show something completely different: that the conduct would not have been profitable for the dominant firm absent its contribution to the maintenance of market power. ${ }^{151}$

3. Alleged Innovation Benefits of Monopoly Should Not Justify a Procompetitive Presumption for Exclusionary Conduct by Firms with Substantial Market Power

Courts should not permit monopolists to justify exclusionary conduct by arguing that their resulting monopoly profits will spur future innovation. As discussed earlier, economic analysis and associated empirical evidence do not support the general claim that a monopoly market structure leads to more innovation. While firms innovate in the hopes of achieving a monopoly, achieving a durable monopoly does not lead to more future innovation. To the contrary, significant evidence suggests that competition, not monopoly, spurs innovation. ${ }^{152}$ It is

${ }^{150}$ See, e.g., Gregory J. Werden, Identifying Exclusionary Conduct Under Section 2: The 'No Economic Sense' Test, 73 Antitrust L.J. 413, 417, 426 (2006) (explaining how the "no economic sense" test is used to distinguish between exclusionary and competitive acts); see also A. Douglas Melamed, Exclusive Dealing Agreements and Other Exclusionary Conduct--Are There Unifying Principles?, 73 Antitrust L.J. 375, 389-403 (2006) (endorsing a similar "sacrifice test").

${ }^{151}$ The Department of Justice unsuccessfully advocated this test to the Supreme Court in Verizon Commc'ns Inc. v. Law Offices of Curtis V. Trinko, LLP, 540 U.S. 398, 407-11 (2004), and to the D.C. Circuit in United States v. Microsoft Corp., 253 F.3d 34, $58-59$ (D.C. Cir. 2001), which affirmatively rejected it in favor of a focus on competitive effects.

${ }^{152}$ See Baker, supra note 15, at 13-14 ("[G]reater competition is commonly more important for enhancing innovation incentives than the greater appropriability that a monopoly could confer."); Baker, supra note 103, at 576 ("[A]ntitrust intervention can systematically promote innovation competition and pre-innovation product market competition, which will encourage innovation ...."); Shapiro, supra note 102, at 362-63, 401 ("[I]nnovation, broadly defined, is spurred if the market is contestable; that is, if multiple firms are vying to win profitable future sales.”). 
fear of losing the monopoly that spurs the monopolist. Moreover, if the exclusionary conduct raises competitors' costs or barriers to entry, innovation by potential rivals would be expected to fall, which would reduce the monopolist's need to innovate. Permitting this justification also is contrary to overarching antitrust policy favoring an unencumbered competitive process. It also distorts the incentives for monopolists in favor of exclusionary strategies rather than competition on the merits.

4. Complaints About Exclusionary Conduct by a Competitor Neither Justify a Procompetitive Presumption nor an Imposition of a Higher Evidentiary Burden on the Plaintiff

Competitors serve as an early tripwire for competitive concerns about exclusionary conduct. The interests of foreclosed competitors are consistent with consumer welfare in exclusionary conduct cases since raising rivals' costs will lead to higher consumer prices, so the rivals' harm is antitrust injury. The shibboleth that antitrust law protects "competition, not competitors" should not be used to dismiss legitimate exclusionary conduct concerns of rivals or to attack the credibility of their testimony on the grounds that it reflects their "self-interest[s]."153 Nor should courts treat the testimony of competitor witnesses as less credible than the testimony of the executives of a defendant's company, whose testimony also reflects their own interests, which may be to achieve or maintain market power. "Shoot the messenger" as a defense strategy should be rejected as distraction.

\section{Conclusion}

${ }^{153}$ United States v. AT \& T Inc., 310 F. Supp. 3d 161, 211 (D.D.C. 2018). 
The capacity of antitrust law to identify, redress, and deter anticompetitive exclusionary conduct has been systematically weakened over time. While there was a need for certain adjustments fifty years ago, continued reliance on the assumptions and presumptions that led to an overly permissive approach are no longer supportable. The evidentiary burdens courts now impose on plaintiffs are overly demanding and likely lead to under-deterrence. They are also handicapping the ability of antitrust enforcement to respond to the challenges of today's technology-driven economy.

We have explained how current law is flexible enough again to adjust its standards in light of modern economic analysis informed by decision theory. We have also proposed a number of guiding principles to update standards of proof, including the use of presumptions. In this way, the sliding-scale "enquiry meet for the case" can be implemented for the current market environment. As now-Judge Frank Easterbrook once argued, there is no natural "ratchet" in antitrust law that channels its evolution only in one direction. ${ }^{154}$ For Easterbrook, that meant imposing more demanding standards of proof. But the same lack of ratchet should apply today as the continuing evolution of technology markets and modern economics suggest that greater antitrust vigilance is needed.

${ }^{154}$ Frank H. Easterbrook, Is There a Ratchet in Antitrust Law?, 60 Tex. L. Rev. 705, 706 (1982). 